July 30,2014

\title{
Punching Above Their Weight through Policy Learning: Tobacco Control Policies in Ireland*
}

\author{
Donley T. Studlar \\ School of Government and Public Policy \\ University of Strathclyde \\ McCance Building \\ 16 Richmond Street \\ Glasgow G1 1XQ \\ UNITED KINGDOM \\ donley.studlar@strath.ac.uk
}

${ }^{*}$ An earlier version of this paper was presented at a colloquium at the University of Stirling. Thanks to the participants there, especially Paul Cairney, for their comments. I am grateful to the people in Ireland who agreed to talk to me about this issue, the reviewers of the manuscript, and to Michael Marsh (Trinity College, Dublin) for his stimulating thoughts on this topic over the years.

\begin{abstract}
:
Ireland's tobacco control policy today is recognised as one of the strongest in Europe and the world, largely on the basis of its first-in-the world general workplace smoking ban in 2004. However, it is insufficiently recognised that Ireland has persistently and deliberately developed tobacco control policies since the 1970s, a longer period than most countries. Using a five-fold analysis of factors influencing tobacco policy agendas, socioeconomic setting (including public opinion), networks, institutions, and ideas (including scientific information and diffusion), this paper explains policy development in Ireland over the long term. It demonstrates how a small country, not dependent on tobacco growing or a domestic tobacco industry but also having only a small research and bureaucratic capacity, has managed to create a strong tobacco control policy. Even though it is an EU member, Ireland has utilised diffusion of research and policy in the English-speaking world, especially paying close attention to the United States, to develop its position as a world policy leader in tobacco control.
\end{abstract}

Keywords: smoking; policy learning; diffusion; policy agenda; United States; European Union 


\section{Punching Above Their Weight through International Policy Learning: Tobacco Control Policies in Ireland}

Ireland has an established worldwide leadership role in the fight against tobacco. (Towards a Tobacco Free Society: Report of the Tobacco Free Policy Review Group, 2000, p. 40)

The need to transpose European Union legislation combined with the new revelation about the marketing practices of the industry presents us with a unique opportunity to review our arrangements (Towards a Tobacco Free Society 2000: 41).

From a layperson's view observing events in America, the key element to me is the addictive content in tobacco-about which information was withheld from the public. Health Minister Micheál Martin (Sheridan 2000)

\section{Introduction}

In recent years, the Republic of Ireland has won recognition for its first-in-the world general workplace smoking ban in 2004 (Gilmore 2005; Currie and Clancy 2010; Howell and Allwright 2005; 2007) as well as for its overall high standing in Europe on tobacco control measures (Joossens and Raw, 2007; 2008, 2011; 2014; Currie 2013a; Studlar et al. 2011; Currie and Gilmore 2013). This strong position is likely to continue with the 2013 announcement that Ireland will be the second or third country in the world to introduce 'plain packaging' of cigarettes, after Australia initiated this. ${ }^{1}$ Yet even prior to 2003, when the workplace ban was introduced, Ireland had been playing a leading role in tobacco control in Europe and indeed the world.

Unfortunately, even early general studies of tobacco policy adoption such as Roemer (1982; 1993), while acknowledging Ireland's early role in putting rotating health warnings on cigarette packages, otherwise underplay Ireland's tobacco control policies in favour of more detailed discussion of those in other countries. The development of this longer record of tobacco control policy remains to be examined, from its beginnings in inheriting a weak tobacco control regime upon independence from the United Kingdom in 1922 and for many decades thereafter to the stirrings of what has become its strong international role in the 1970s and1980s. As others have focused on the impact of Ireland's policies (Joossens and Raw 2011; Currie 2013a; Currie 2013b; Currie and Gilmore 2013), this paper will attempt to explain the process of formulating strong tobacco control policies in Ireland over the long term, using the five factors posited by Cairney et al. (2012) that influence tobacco control policy adoption-institutions, agendas, networks, ideas, and socioeconomic setting, including public opinion.

Not only in tobacco control, but also in other policies, Ireland has been neglected in comparative studies. For instance, it was not incorporated into the original theoretical or empirical formulation of Castles' (1993) influential 'families of nations' concept although later empirical tests do include Irish data (Obinger and Wagschal 2001; Castles and Obinger 2008). Such studies indicate, as one might expect, that Ireland is part of the 'English-speaking world' generally, or, within Europe, the 'Northern periphery' of strong tobacco control (Cairney et al. 2012). While Ireland may appear in broad cross-country quantitative studies of public policy, 
it has only rarely been considered in qualitative comparative studies, except as an exceptional case on abortion policy (Outshoorn 1996; Mahon 2001; Kurzer 2001) or during its period of economic growth as the 'Celtic tiger' and the corresponding shock decline (Chari and Bernhagen 2011). A study of the development of the first EU 1998 Tobacco Products Directive (TAD1) (Duina and Kurzer 2004), while acknowledging the role of smaller states in advocating for the directive, does not analyse Ireland's particular role. ${ }^{2}$ In summary, despite its membership of the EU since 1973, Ireland has yet to become 'normalised' in policy studies.

Similarly, there have been no general studies of tobacco policy specifically on Ireland although it is included in some broader comparisons (Cairney et al. 2012; Currie, 2013a; 2013b, Joossens and Raw 2007; 2008; 2011; 2014). Some public health studies focus on particular policy adoptions and impacts, especially the workplace smoking ban (Howell 2004; McNicholas 2004; Barry 2005; Howell and Allwright 2005, Howell 2012; Currie and Clancy 2010). The only book on Irish tobacco control policy adoption, concerning the struggle for the 2004 ban, was written by a public relations professional (Gilmore 2005). Thus it is appropriate that Ireland receive the attention that tobacco control policies in other leading countries such as Canada, Australia, New Zealand, Norway, the United Kingdom, and the United States have received in public policy analysis (Studlar 2002; 2005; 2007; Baggott 1988; Cairney 2009; Levy et al. 2013; Cairney et al. 2012).

This paper will proceed to analyse how tobacco control policy has developed in Ireland, based upon multiple sources, including documents, case studies, quantitative data, and interviews with those involved in the policy process. The overall conclusion is that Ireland has developed a strong profile in tobacco control, beginning in the mid-1980s and continuing to the present, because of favourable socioeconomic circumstances, early entrance of tobacco control issues on the policy agenda, the continuous development of policy in the health ministry and its increased influence in comparison to the finance ministry, the political entrepreneurship of Health Minister Micheál Martin (2000-2004)and a long-serving civil servant in the Health Ministry, Tom Power, in the early 2000s, and domestic and international networks that led to an unusually strong incorporation of both research and policy instruments from other jurisdictions, especially those in the United States and other parts of the English-speaking world as well as mandates to adopt EU tobacco control policies. What most distinguishes Ireland's adoption of strong tobacco control measures, even in the face of severe post-2007 economic problems, is it willingness to base its policy upon learning through policy transfer/diffusion ${ }^{3}$ of evidence and policy from other jurisdictions, more on a voluntary basis rather than on coercion from the EU. Ireland was usually ahead of the EU on the utilisation of specific policy instruments.

\section{Theory}


There are two strands of research attempting to explain different parts of the policy process on tobacco in Ireland. The Public Health approach attempts to gauge the joint and individual impact of multiple instruments (interventions) such as taxation, cessation, media campaigns, health warnings, advertising/promotion restrictions/bans and smoking restrictions/bans (Joossens and Raw, 2008; 2011; Currie 2013a). As indicated, relatively little of this literature is concerned with policy development, except for case studies on the world renowned workplace smoking ban (Currie and Clancy 2010; Howell and Allwright 2005; 2007).

On the other hand, there are now several Political Science studies, often cross-national in nature, that provide general explanations for the adoption of policies in Western democracies (Studlar, 2002; 2004; 2005; 2007; Farquharson 2004; Marmor and Lieberman 2004; Wilensky 2002; Albæk et al. 2007; Baumgartner and Jones 1993). Ireland specifically has been included in some of these broadly comparative studies (Studlar 2009; Studlar et al. 2011; Toshkov 2013). The most widely applicable exposition is Cairney et al. (2012), who organise their explanation of tobacco policy change in various jurisdictions across five factors that might influence policy: agendas (framing), socioeconomic setting (including smoking prevalence, economics, and public opinion), networks (pro and anti-tobacco groups and their allies), institutions (relevant ministries in the executive, the legislature, the judiciary, the EU for European countries, and political parties) and the knowledge basis (science and policy learning, including policy transfer/diffusion). In an attempt to make the Irish case as comparable as possible to their jurisdictions (US, UK, Canada, Australia, New Zealand, Japan, EU, developing countries grouped regionally, and $\mathrm{WHO}$ ), I shall follow this format.

Cairney et al. (2012) find that stronger tobacco control measures tend to be adopted in countries in which smoking prevalence declines, where public opinion becomes more favourable toward control, where the issue becomes addressed on the political agenda as a health/secular morality rather than an economic development issue (even if there is a certain amount of leapfrogging in calibrations of policy instruments), where the health ministry is robust and eventually able to gain 'ownership' of tobacco policy over other ministries involved (finance, agriculture, trade), where a strong NGO anti-tobacco network develops to oppose and eventually supersede the influence of tobacco growing and manufacturing interests, and which are willing to learn from research findings and policy instruments adopted not only in their own country, but also in others as well as through international organisations and NGOs. This paper will examine whether these conditions have been met in Ireland specifically, and which ones have been more important in developing Irish tobacco control policy.

\section{Methods}

The analysis relies on process-tracing through a mixture of primary documents, secondary accounts, and interviews with eight anonymous people (academics, civil 
servants, and elected politicians) involved with tobacco policy in Ireland (October 2013). Where possible, different interpretations have been checked against one another in an attempt to clarify the evidence. The emphasis is on developing both a detailed timeline of tobacco policy development in Ireland as well as applying the model of tobacco policy outlined above to help explain what was done and not done, both over the long term and at particular times. Since there is a paucity of historical accounts of tobacco policy in Ireland, this is a contribution to historical as well as contemporary policy analysis.

\section{The Agenda and Framing of Tobacco Control in Ireland}

\section{(Table 1 about here.)}

Table 1 shows the most widely-accepted delineation of eras of tobacco policy in the Western world, broadly a slow shift from a promotional 'political economy' orientation towards a 'public health' focus, with suggestions of 'secular morality' considerations as well (Brandt and Rozin 1997; Cairney et al. 2012). Ireland would seem to fit readily into this account once it achieved independence in 1922. Before that time, of course, it was part of the United Kingdom's policies, for instance the support of smoking by troops as a morale booster in World War I. There is no evidence of government promotion of tobacco manufacturing during the second era, as all tobacco companies operating in Ireland are branch plants of transnational enterprises (see below). Ireland was largely an agricultural country at this time, but it does not have a climate conducive to tobacco growing. Despite having a relatively low GDP per capita for a Western democratic country, tobacco consumption increased in Ireland. This continued even after the alarming and authoritative health reports of the 1960s as Ireland became more prosperous and cigarettes more affordable, in line with the 'tobacco epidemic model' (Read 2006; Lopez et al. 1994). It was during the third era, beginning in 1950, that Ireland, along with other countries, began to question the role of smoking in society. Since Irish research capacity on tobacco-related diseases was and is very low, no domestically-produced report influenced policy at this time. But the path-breaking publications on the hazards of tobacco smoking in the United Kingdom and the USA, starting in 1950 (Doll 1998), must have come to the attention of Irish health professionals, particularly those engaged in public health. As in other Western democracies (Cairney et al. 2012), policy shifts toward tobacco control began in the 1960s, as indicated in Table 1 and the Appendix. Subsequently, tobacco policy eras in Ireland have closely matched the general Western ones.

The agenda of tobacco policy in Ireland has changed considerably, starting slowly in the 1960s and 1970 s and accelerating with the turn of the new century. From an occasional issue, tobacco policy has now turned into a regular, continuing policy on the agenda, as indicated by the Appendix. Until the mid-1980s, Ireland followed the early development model for tobacco control in banning some highly visible advertising, such as on television and radio, taxing cigarettes heavily ${ }^{4}$, promoting some health education, and having health warnings on packages (see 
Table 3). ${ }^{5}$ Already this made Ireland one of the leading restrictionist countries although this was not broadly recognised (Roemer 1982; Sasco et al. 1989; Currie 2013a) For instance, Ireland was the fourth country in Europe to impose cigarette package warnings, in the face of tobacco industry resistance, and only the second in the world to have rotating warnings (Hiilamo et al. 2012). From their authorisation in 1979, Ireland had two innovative policies. One was to ban discounted pricing of cigarettes in order to minimise price competition; the second was to control the allowable advertising budgets of the tobacco companies. Even though health ministers were empowered through legislation to take even stronger steps, especially on advertising and promotion, they were reluctant to do so for fear of the economic repercussions (Barry 2005). ${ }^{6}$ Nevertheless, much of the credit for Ireland's relatively strong early standing in tobacco control, according to some interviewees, goes to Health Minister Charles Haughey (1977-1979), who, although a smoker, recognised the importance of the issue.

In the mid-1980s, the tone of the policy agenda on tobacco began to change into a more anti-tobacco discourse in Ireland, as in other Western democracies. Scientific research in other countries raised concern over the health hazards of second hand smoke, broadening the issue from one of individual choice to more general welfare (Cairney et al 2012). With the advent of the EU's cigarette tax harmonisation and its 'Europe Against Cancer' programme (from 1985), Ireland continued to have high taxation and banned smokeless tobacco (before the EU took action). Not only did Ireland have strong warning labels on packages, but its resistance to imported cigarettes without any warning labels stimulated the EU harmonize package warnings within the member countries in 1989 (European Commission 2004: 120). Legislation on air pollution in Ireland, stimulated by coalfired smog in Dublin, made the Irish especially sensitive to the environmental issues raised by second hand smoke (Joint Committee on Health and Children 1999; 2001; Currie and Clancy 2010)

In the early late 1980s and early1990s Ireland began to adopt regulations implementing the powers already granted to the health minister for further limitation of advertising, promotion and non-smoking areas. Anti-smoking campaigns became more regular and better financed. NGOs began to sponsor cessation clinics. Thus, the instruments used to combat tobacco consumption became more diversified as well as stronger. From 1986 periodic public reports from the health ministry documented the morbidity and mortality problems facing the country, including those resulting from smoking, especially cancer (see Table 2). Yet tobacco was not a priority for the Health Ministry, which was responsible for a number of persistent and conflict-ridden issues, especially concerning financing and coverage of health care as well as labour relations (Joint Committee on Health and Children, 2001; Gilmore 2005; Currie and Clancy 2010). In the famous words of the former Health Minister Brian Cowen (1997-2000), heading that department 'was like serving in Angola' because of the landmines that one might encounter (Gilmore 2005: 17) ${ }^{7}$

\section{(Table 2 about here.)}

Ireland's augmentation of its tobacco control policies in the late 1990s and early 2000s made it a recognised European and world leader within a few years. The budget for 2000, agreed in 1999, provided for a 50 p. increase in cigarette taxation. 
This was not only the largest such increase ever, but it was unusual for Ireland as a tax dedicated to health spending. There were continuing demands for more tobacco control measures from a public health coalition, consisting of the Irish Heart Foundation, Irish Cancer Society, Action on Smoking and Health (ASH) and trade unions concerned about their members; exposure to second hand smoke (Howell 2004; Howell and Allwright 2005). As more documents about earlier tobacco company knowledge of the hazards of their products, in contradiction to their public statements, were revealed in US litigation, in 1998 a joint Oireachtas Committee on Health and Children was formed to investigate tobacco policy in Ireland and abroad. After a year containing 13 hearings in Ireland and visits abroad to the US and Canada, this committee produced the influential document, A National Anti-smoking Strategy - A Report on Health and Smoking (Joint Committee on Health and Children 1999). The report recommended a comprehensive approach of stronger tobacco control measures to make this a 'key priority' in health, including a workplace smoking ban.

As indicated in the Appendix, the Health Ministry produced its own report in response(Towards a Tobacco Free Society: Report of the Tobacco Free Policy Review Group 2000: 7), largely following the recommendations from the Joint Committee. The subsequent adoption of these into policy constituted the first Tobacco Control Strategy for Ireland. The report was presented under the following general framework:

4 key strategic objectives:

1. To change attitudes

2. To help people give up smoking

3. To protect people from passive smoke (ETS)

4. To focus on children.

7 tier action plan:

1. Better communication and education

2. Specific support for smokers to quit

3. Tougher regulation of the tobacco industry

4. Further protection against ETS

5. Building better compliance with the law

6. Extending ownership

7. International co-operation.

A second Oireachtas report further examined tobacco hazards and costs, the state of knowledge of the tobacco industry, youth smoking, environmental tobacco smoke, and the problem of enforcement. The subcommittee produced 20 specific recommendations, including a that 'smoking be banned in all public houses to protect the health of staff of such premises as well as the health of non-smoking adult customers' (Joint Committee on Health and Children 2001: 70). The government took action on these reports in the next few years, most famously in the form of the first-in-the world general workplace smoking ban through regulations announced in 2003 and implemented in 2004 (Gilmore 2005). At this point the world 
began to notice Ireland as an anti-tobacco beachhead whose policies spread elsewhere as they were deemed successful (Barry 2005; Gilmore 2005; Read 2006; Currie and Clancy 2010).

Over the next decade, tobacco policy in Ireland was consolidated as more of the policies authorized in the Public Health acts of 2002 and 2004 were implemented, including minimum package sizes, a total ban on cigarette advertising at point of sale, and graphic package warnings. Martin's immediate successor as Health Minister, Mary Harney (2004-2011) was judged by some anti-tobacco campaigners to be the least sympathetic to tobacco control of any recent holders of that position (interviews). Nevertheless, by 2013 the agenda set out in 2002 and 2004 largely had been satisfied, the 'rationalisation' budget cuts in government services were completed ${ }^{8}$, the smuggling problem had been addressed (Jennings 2011), and health charities were pressing for more action. While the economic problems led to a reduction of staff in tobacco control, it also made less costly public health prevention more valuable as a tool (interview). Thus the Irish government, with the physician James Reilly as Health Minister, undertook an ambitious new strategy, the first one presented since 2000-2005, including plain packaging, denormalisation, and a reduction in prevalence to five percent by 2025 (Tobacco Free Ireland: Report of the Tobacco Policy Review Group 2013). Subsequently, in an unusual move, the government took over a private member's bill on banning smoking in cars with children (Government to press ahead with ban on smoking in cars, 2014).

But before new policies could be developed, problems in regard to Ireland's persistently high taxes on cigarettes, especially related to smuggling, had to be resolved (Currie 2013b). ${ }^{9}$ As in other policies, tax increases in Ireland generally have been incremental, although there have been a few exceptional years, notably in 2000 , when the rise was dedicated to finance improvements in health, and in 2009, when the financial crisis made a supplemental budget necessary. For 25 years, until the 2005 and 2006 budgets, there were regular increases in cigarette (and alcohol) taxes (Reed 2011; Chaloupka and Taurus 2011). Perhaps this first 'tax pause' was intended as compensation to the protestors over the workplace smoking ban (Gilmore 2005). Nevertheless, substantial increases followed in 2007-2009 (Currie $2013 b)$. Subsequently there has been an ongoing debate about the relative impact of high taxes and smuggling, which came to a head in the wake of the euro austerity crisis and the increase in smuggling to an estimated 20-25 percent of cigarettes consumed (Jennings 2011). Penalties for smuggling were increased, but there also were no tax increases on cigarettes for two years, 2010 and 2011 (Jennings 2011; Reidy and Walsh 2011; Reed 2011; Currie 2013b). Despite these controversies, Currie (2013a) finds that Ireland still has the highest weighted average price in the EU. Irish tobacco is so expensive because of high company mark-ups on the product as well as the government's emphasis on excise rather than ad valorem taxes (Howell 2012; Reed 2011; Nguyen et al. 2013). The Irish Cancer Society and Irish Heart Foundation have argued, unsuccessfully thus far, for a cap on tobacco company profits by limiting the wholesale price they can charge, along with higher taxes (McCabe 2013). Any such price limitation would have to be referred to the EU Commission (interview). 
Aside from taxes, the framing of the tobacco issue in Ireland was somewhat different than in other Western democracies. In Baumgartner and Jones's (1993) terms, this was a 'Downsian mobilisation' from society as well as elements within the government attempting to replace the former voluntary arrangements for protection from secondhand smoke with stronger, government-enforced regulation. In order to be successful, this reform had to re-frame the issue in favourable ways. Perhaps only in the USA (Bayer and Colgrove 2004) were threats to children and youth emphasised as much. US Food and Drug Commissioner (FDA) David Kessler' famous characterisation of smoking as a 'pediatric disease' was used repeatedly in official documents and testimony in Ireland (Joint Committee on Health and Children 1999; Towards a Tobacco Free Society: Report of the Tobacco Free Policy Review Group 2000). Perhaps this stemmed at least partly from the fact that the relevant Oireachtas committee with jurisdiction was concerned with Children and Health. Another comparatively unusual frame emphasised the second hand smoke threat to workers health (rather than the health of the public or of smokers themselves), a highly relevant strategy in passing the workplace smoking ban but one that also featured in earlier documents, as indicated above. Supported by the relevant trade unions, the issue became one of health equity for all workers rather than focusing solely on tobacco hazards to individuals (Howell 2004; Gilmore 2005; Read 2006). As noted earlier, the 1980s struggle over smog pollution also was invoked.

A lot of attention was paid to results from the 1990s litigation in the USA, and urgings of similar action in Ireland. The latter was not carried out (see below) but, as indicated, discussion of potential litigation made the tobacco companies leery of cooperating with the special committee and the government. While there were political economy arguments voiced, in terms of the potential economic effects, positive and negative, of proposed actions, the stifled voice of the industry reduced the invocation of this frame. It became a particular source of debate, however, during 2003 when the publicans (rather than the tobacco manufacturers or sellers) became the leading opponents of the workplace smoking ban (Gilmore 2005; Read 2006).

As Baumgartner and Jones (1993) indicate, when the agenda begins to shift, the time is ripe for political entrepreneurship, in the form of political and bureaucratic figures willing to take risks to advance a reform agenda that, if successful, would not eliminate struggle but would change the dominant perceptions of it more securely in the foreseeable future. This occurred in Ireland through the efforts of a committed, unusually long-serving civil servant in the Health Ministry, Tom Power, and Health Minister Micheál Martin in the in the early 2000s, and may be happening again through Minister James Reilly (see footnote 6). Martin's role, especially in the workplace smoking ban, has been well documented (Gilmore 2005; Read 2006) as he embraced the challenge of including bar workers in the legislation, survived fierce criticism from within his own party, obtained the support of the Taoiseach, consulted widely on scientific evidence, worked with nongovernmental as well as governmental partners, made certain tactical concessions, and oversaw preparation of the public for the changes. In effect, he staked his career and reputation on successfully passing and implementing this legislation. He then continued his ministerial career, rising to his current position as leader of the Fianna Fail opposition to the government. Few other political leaders have managed to build their careers so much on perceived success in tobacco control policy. While Martin was the public face of Ireland's tobacco control policy, Tom Power was the 'inside', bureaucratic 
and organisational one, well respected both internally and in international circles (interviews, Connolly and McGoldrick 2003).

\section{Socioeconomic Setting}

Ireland's socioeconomic setting for tobacco was conducive to stronger control efforts. Smoking prevalence rates for Ireland differ considerably depending on the source, one of the problems with low research capacity (European Commission 2004; Currie et al. 2013; Reed 2011). Furthermore, in recent years the influx of immigrants, especially from Central and East European countries has counteracted lower native smoking, especially in recent years. While the rates have dropped considerably since the 1970s, despite the increasing affordability of cigarettes, remaining smokers were consuming more cigarettes, and the morbidity and mortality from smoking were high in Ireland, part of a general pattern in which in the mid1990s for Irish health indicators being below EU-15 averages (Towards a Tobacco Free Society: Report of the Tobacco Free Policy Review Group 2000). Some considered that a 'plateau' had been reached in tobacco consumption, which was an impetus for action at the turn of the century (Barry 2005; Read 2006).

As in most countries, there was not a public clamour for tobacco control, but the public was receptive to political leadership advocating it, a situation of 'permissive consensus' (Key 1964; Cairney et al. 2012). This allowed for actor agency in the form of messrs. Martin and Power (Read 2006). As Baumgartner and Jones (1993:85) argue for the general case, 'policy entrepreneurs take advantage of favourable public opinion and quickly move to ensure a quick assignment by government officials to an encouraging institutional venue'. Since including pubs and restaurants in the workplace smoking ban was perceived as being a major challenge to Irish cultural practices, the Health department carefully prepared the ground for its implementation through a public information campaign, coordinated with its nongovernmental partners, through the media, seminars, publication of healthrelated research, and direct mail, targeted at particular groups as well.

The permissive consensus was demonstrated most dramatically by the growth in support for the workplace smoking ban once it was instituted (Gilmore 2005; Fong et al. 2006). Even in the wake of the economic downturn of the past few years, public support for tobacco control measures has remained high, well above the EU average (Studlar 2009; Eurobarometer 2012). Thus there has been a favourable setting for the government to introduce more restrictive tobacco control legislation.

\section{Policy Networks}

The configuration of the pro- and anti-tobacco networks in Ireland were similar to those in other Western democracies at the time. There was no domestic leaf growing or locally-owned tobacco manufacturing; in fact, since 2004 no cigarettes are manufactured in Ireland (interview). Thus pro-tobacco interests were less well placed than in other European countries although they did have connections at high political levels. There is evidence that they have been influential in the past (Barry 2005; Gilmore 2005). Their common corporate voice has been the Irish Tobacco Manufacturers Advisory Committee (ITMAC) although in recent years the individual 
companies have begun to speak for themselves more frequently. As noted, there have usually been three major tobacco companies in Ireland, but, because of international arrangements, sometimes these firms sold an even wider variety of cigarettes. Recently the three firms have been JTI Ireland (formerly Gallaher, now the Irish subsidiary of Japan Tobacco International), P. J. Carroll (Irish subsidiary of British American Tobacco), and John Player and Sons Ltd. (Irish subsidiary of Imperial Tobacco, also distributer of Philip Morris products in Ireland). Recently these three have had approximately 50, 35, and 15 percent of the Irish market, respectively. Since these three firms were branch plants of overseas companies, the situation resembled that in a country of similar size such as New Zealand, also a strong tobacco control jurisdiction, rather than Denmark, where a domestically-based tobacco company with a strong hold on the local market has helped make that country hesitant on tobacco control measures (Albæk et al. 2007; Cairney et al. 2012). Furthermore, the companies were subject to accusations in Oireachtas hearings that, as part of a globalised tobacco industry, they must have the same knowledge of nicotine addiction and health hazards that their counterparts, especially in the US, were revealed to have (Joint Committee on Health and Children 1999; 2001; Towards a Tobacco Free Society: Report of the Tobacco Free Policy Review Group 2000).

While the industry in Ireland also had support from vendors, the hospitality industry, and media dependent on its advertising, some of its strongest backing came from the publicans in the association of smoking with drinking, especially in the debate over the workplace smoking ban. The primary opposition to the government regulations was the Irish Hospitality Industry Alliance (IHIA) (Barry 2005; Gilmore 2005; Read 2006). There is also a branch of the smokers' rights organisation of the UK, Forrest Eireann, financed by the domestic industry. While these links may have helped the industry resist earlier regulation, especially a comprehensive advertising ban in the 1980s (Barry 2005) as well as instituting a turn toward voluntary agreements for second hand smoke limitation in the early 1990s (Howell 2004; Read 2006), they have proven weaker in recent times.

In contrast, some of the strongest opposition to the industry during that conflict came from unions, especially Mandate representing the majority of bar workers, who had become convinced by the evidence on second hand smoking hazards particularly through an OTC-sponsored presentation of the international evidence of the hazards of second hand smoke (Currie and Clancy 2010) and, more generally, through persistent targeting efforts of the anti-tobacco groups (Howell 2004).

This was a critical, and unusually vociferous, gain for the anti-tobacco groups. Although some medical organisations expressed concern about the effects of smoking earlier, organised opposition to tobacco in Ireland did not begin in earnest until the early 1990s, somewhat later than in other English-speaking democracies (Cairney et al. 2012). When the Irish Heart Association and the Irish Cancer Society decided to take political action against smoking, they formed Action on Smoking and Health (ASH) in 1991 especially to conduct this struggle. The Irish ASH had no formal connections with its similarly-named counterparts in other countries. Nevertheless, Irish NGOs became part of a loose international network of antitobacco groups through organisations such as the Union for International Cancer 
Control (UICC), the World Conference on Tobacco Or Health (WCTOH), and the European Network on Smoking Prevention (ENSP), providing forums for exchanges of information and policy ideas (interviews). The Irish anti-tobacco NGOS have worked cooperatively with the Ministry of Health in health promotion campaigns (Joint Committee for Health and Children 1999: 70). While these three were the main groups advocating for greater tobacco control, others, such as the Irish Medical Organisation, the Irish College of General Practitioners, the Asthma Society, and other medical and health-related groups also provided support at times, especially in the controversy surrounding the implementation of the workplace smoking ban. That legislation also benefited from the hard-won support from the three largest trade unions in the country-Mandate, SIPTU (hotel workers) and IMPACT (health care workers); Gilmore 2005: 21; Read 2006; Currie and Clancy 2010). The health department-NGO alliance was important in recent policy battles especially for the workplace smoking ban (Currie and Clancy 2010). One interviewee commented that this was the high water mark of NGO unity in support of a government policy. In 2014 the Royal College of Physicians of Ireland has announced formation of a Tobacco Control Policy Group to support the government's Tobacco Free Ireland goals (Towards a Tobacco Free Society 2014)

As indicated previously, the CEOs of the three major tobacco companies in Ireland in the early 2000s (John Player and Sons, P.J. Carroll, and Gallaher), were fearful of litigation, especially that the government might emulate jurisdictions in the USA. Such a possibility was under consideration by the relevant committees and the government, as indicated in a prominent press report (Sheridan 2000). Perhaps the tobacco company representatives also remembered what had happened to their counterparts in the US in legislative hearings in 1994 when they denied knowledge of the health hazards of tobacco. Thus the tobacco companies engaged in some sharply-worded letters with the 1999 committee and refused to give evidence to subcommittee in 2001.

By the late 1990s industry access to high levels of the Health Department ended when Tom Power refused to talk with them (interview). Nevertheless, the Finance Ministry continued to view tobacco as 'an ordinary consumer product' and to consult the industry on tax issues (Joint Committee on Health and Children 1999; Jennings 2011). Finance has continued to rely on cooperation with ITMAC, including giving credibility to industry estimations on tax and smuggling matters; this has led anti-tobacco NGOs to commission alternative analyses (Jennings 2011; Reidy and Walsh 2011; Reed, 2011; Chaloupka and Taurus 2011; Nguyen et al. 2013). There also was concern when tobacco industry representatives met with the Irish Prime Minister in 2013, but this did not prevent the Health Minister's subsequent announcement of further measures to combat smoking, including plain packaging. In summary, over the past 20 years, the anti-tobacco network seems to have become ascendant and the industry network has been in retreat to the extent that it has been at least partially de-legitimised in the eyes of officeholders, but more so in health matters than on taxation.

\section{Institutions}

Political institutions play an important role in tobacco policy. In Ireland, the institutions involved have been the normal ones of executive agencies, especially the 
Health and Finance departments, but also several others. The Labour Affairs Department has responsibility for enforcing the workplace smoking policy through environmental health officers (Gilmore 2005; Read 2006). The Justice Ministry has had to deal with questions of litigation from or towards the tobacco industry (Reilly 2014). This issue involves the judiciary as well as the executive, of course.

Furthermore, recently the Trade Ministry as well as Irish political leaders have been the recipients of intense lobbying from general US business organisations and political representatives questioning whether Ireland's plain packaging legislation is compatible with the US-EU Free Trade Agreement under negotiation as well as World Trade Organisation (WTO) rules on intellectual property (Beesley 2014). Ultimately, whatever the day-to-day decision-making, the Taoiseach must determine the overall direction of government policy.

There are three key relationships for tobacco policy among Irish institutions. The first is between legislature and executive in policy development, which has varied. In the earlier days of the late 1990s, parliament took the lead although the executive quickly followed (Joint Committee on Health and Children 1999; 2001 Towards a Tobacco Free Society: Report of the Tobacco Free Policy Review Group. 2000). More recently, the executive has initiated more policies, either through legislation or regulations. But as indicated previously, in 2014 the government decided to sponsor what was originally a Private Member's bill banning smoking in cars with children.

Tobacco policy largely has been a nonpartisan issue in Ireland (Barry 2005; Read 2006; Currie and Clancy 2010). Measures in Ireland have been introduced by governments and health ministers of different parties, for instance Fianna Fail in 2004 and Fine Gael in 2013. The 1999 and 2001 Oireachtas investigations, as well as support for the 2004 workplace smoke regulations were not subjects of partisan conflict. The committee reports were unanimous recommendations in both cases. There was more dissent on the workplace smoking regulations from within Health Minister Martin's party than from the other parties (Gilmore 2005; Read 2006). Thus Ireland confirms previous general findings that tobacco control legislation does not fit the general European 'party government' model in terms of generating party conflict (Cairney et al. 2012; Studlar et al. 2011; Toshkov 2013).

The second key relationship is the relative views and influence of tobacco of the Health and Finance departments within the executive. Traditionally the Finance Department has dominated tobacco policy through its concern about maintaining the 'cash cow' of reliable revenue from tobacco sales. Because of their addictive nature, the demand for tobacco products is relatively inelastic. As indicated previously, in recent years Finance has exhibited an ambivalent attitude toward tobacco tax increases because of concerns about smuggling and resultant loss of revenue. Even in the Finance Department views, however, views have changed somewhat. When the Health Department under Mary Harney was reluctant to make tax proposals, NGOs commissioned studies advocating increases, and eventually the Irish Cancer Society was brought into an official Advisory Group on Tobacco Smuggling, which led to major increases in penalties in the 2010 Finance Act, perhaps a compromise also involving the temporary cigarette tax 'pause' (interviews; Jennings 2011). 
In Ireland as in several other democracies, the increased attention to smoking as a policy problem has led generally to an increase in influence of the Ministry for Health. Especially under the leadership of civil servant Tom Power in the late 1900s and early 2000s, those sections concerned with tobacco control in this ministry played an important role in developing the evidence base for policies, including close connections with their counterparts in other English-speaking countries (interview).

The third key institutional relationship is between policy passage and enforcement. Parliamentary committee hearings revealed that during the $1990 \mathrm{~s}$ enforcement of tobacco control policies was not very effective; the Health Ministry admitted its shortcomings and pledged to do better (Joint Committee on Health and Children (1999; 2001; Towards a Tobacco Free Society: Report of the Tobacco Free Policy Review Group 2000). Subsequent reports indicate that thus the civil servants in the Irish Health Ministry and the Labour Affairs Ministry (Health and Environment) have risen to the challenge by enhancing their enforcement capacity (Howell and Allwright 2007; Tobacco Free Ireland: Report of the Tobacco Policy Review Group 2013).

As do all other EU member states, Ireland has multi-level governance in tobacco policy (Asare et al. 2009). Since Ireland has had to follow EU directives on tobacco since passage of the Single European Act (SEA) in 1987, European institutions are also important. A decision by the European Council (chief executives of the member states) instituted the 'Europe Against Cancer' programme in 1985, that has led to directives and recommendations on tobacco. Formally, directives are adopted based on a proposal by the Commission and passage by the Council of Ministers (a cabinet minister from each state) and the directly-elected European Parliament. Within the EU Commission (the bureaucracy), several directorates have an influence on tobacco policy. The primary ones are the Health Directorate (DG Sanco) and Taxation, but several others (agriculture, competition, trade, employment, justice, social affairs, and regional policy) are also involved (Studlar 2012). The EU Commission relies for both enforcement and proposals on a regulatory committee composed of bureaucrats representing member countries as well as EU civil servants (Faid and Gleicher 2011). Notably, DG Sanco, under the leadership of former Irish government minister David Byrne, spoke for the EU in the negotiations leading to the 2003 Framework Convention on Tobacco Control (FCTC), in addition to individual member states representing themselves (Mamudu and Studlar 2009). Byrne and a previous Irish Social Affairs Commissioner, Padraig Flynn, have been cited as instrumental in pushing for such EU policies as the TPD and the FCTC (Tobacco Free Ireland: Report of the Tobacco Policy Review Group 2013). Byrne, with strong support from the Irish Health Minister, also helped support Ireland's proposed smoking ban by including such a provision in the EU Commission recommendations for member state domestic policies in 2002-2003 (Gilmore 2005: 26). The European Court of Justice (ECJ) has made some important decisions on tobacco issues, especially overturning the original Tobacco Advertising Directive (TAD1) in 2000, upholding its successor TAD2, and negating Ireland's minimum pricing for tobacco in 2010.

Ireland's relationship to the European Union is complex. From the earliest inception EU tobacco control policy in the mid-1980s, Ireland has been ahead of the EU in some ways, behind in others. Thus the EU has acted as a selective spur, for 
instance in enhancing warning labels in 1991 (European Commission 2004), adopting a comprehensive advertising ban in TAD1, and advocating graphic warning labels. But Ireland legislated on some issues, such as health warnings and smokeless tobacco products, before the EU acted, and continued to legislate a complete advertising ban even after TAD1 was overturned by the ECJ. Most famously, Ireland was the first country in the EU to adopt a workplace smoking ban. The EU also has at times hindered Irish tobacco control, for instance in the delay over the introduction of the workplace smoking ban in 2004 and the ECJ decision against minimum pricing in 2010. The delay in implementing the 2004 workplace smoking ban occurred because, as an executive regulation affecting trade, it had to be checked for transparency and compliance with the SEA, which it passed. However, the government decided to put the ban into legislative form to give it a firmer legal footing as well as making it immune to any further EU delays (Gilmore 2005; Read 2006).

The EU usually trails the tobacco control policies in its more restrictive countries, but their presence in EU councils leads to the consideration of common policies eventually agreed with the fence-sitters and laggards (European Commission 2004; Cairney et al. 2012; Börzel 2002: Studlar et al. 2011). Ireland has usually been among those advocating more restrictive EU policies despite the fact that, as a small state, its capabilities under Qualified Majority Voting are limited. Studies of EU decision making on the 1998 Tobacco Advertising Directive, the 2001 Tobacco Products Directive, and the FCTC negotiations demonstrate Ireland's leadership role, one that has been endorsed by the Oireachtas Committee (Towards a Tobacco Free Society: Report of the Tobacco Free Policy Review Group 2000: 48; Duina and Kurzer 2004; Thomson and Stokman 2006; Guigner 2009; Joint Committee on Health and Children 2001).

On a rotating basis, the member states of the EU have the opportunity to preside over the Council of Ministers for a six-month period, and they always present an agenda that they hope to advance during this term. During Ireland's most recent presidency, for the first six months of 2013, the government eagerly promoted the adoption of a strong version of the emerging proposal for a new Tobacco Products Directive, in which one of the major issues was the regulation of e-cigarettes ${ }^{10}$ (Tobacco Free Ireland: Report of the Tobacco Policy Review Group 2013). In fact, the revised Tobacco Products Directive only was finalised after Ireland's presidency ended. The Irish Prime Minister and Health Minister personally lobbied Irish MEPs in the European Parliament (Taoiseach fights tobacco lobby in EU row 2013; Tobacco Free Ireland: Report of the Tobacco Policy Review Group 2013). Despite the directive being somewhat weaker than Ireland wanted, the Irish government officially welcomed its passage.

Ireland also has taken an active role within the World Health Organisation (WHO), especially the European branch headquartered in Copenhagen, Denmark. This is an institutional involvement that provides broader networking opportunities. It was the WHO that sponsored the initiative and provided the arena for what became the FCTC. According to one interviewee, it was the Irish workplace smoking ban was the model for a similar FCTC provision. Tobacco Free Ireland: Report of the Tobacco Free Policy Group (2013: 37) invokes the WHO-developed MPower model for implementation of the FCTC to introduce the new legislative proposals. 


\section{Scientific Evidence}

Ireland is a small country traditionally lacking research facilities in tobacco independent of the industry itself until the establishment of the Tobacco-Free Research Institute, authorised in 2001 and established in 2004. Even then, the TFRI has suffered from lack of consistent government financial support as well as the consequences of the economic downturn of 2008+. Thus, unlike larger countries, Ireland has produced little primary research on tobacco ingredients, health hazards, and even prevalence. It was only when second hand smoke became a critical issue that the government sponsored an independent scientific investigation on the topic, which was published in 2002, making it the $20^{\text {th }}$ jurisdiction in the world to do so (Allwright et al. 2002; European Commission 2004). That report cited 126 studies from US, Australia, Canada, New Zealand, Japan, France, Luxembourg, Belgium, Switzerland, Hong Kong, and the WHO as well as Ireland (Gilmore 2005: 14) On this as on other tobacco issues, Ireland has relied on the research and policy initiatives of other English-speaking countries and the EU, as indicated previously. The political agenda of tobacco policy in Ireland was stimulated from abroad, especially from the United States. In that sense, while Ireland has become a highly globalised society, not only has it been 'a lot closer to Boston than Berlin' in economic policy (at least until the euro crisis) but also closer to Washington and New York City than to Brussels or London' in tobacco policy lessons (Laffan and O'Mahony 2008).

The 1999 Oireachtas and 2000 reports proposal refer extensively to a variety of US materials, including the ground-breaking 1964 Surgeon General's report, second hand smoke hazards, and policies undertaken by US city, state, and central governments (see below). They also refer to 1990s evidence on tobacco-related controversies in the US, including adoption of the language of the focus on youth smoking from the FDA as well as citation of tobacco company knowledge of cigarette ingredients and health hazards, based on documents released in state-based litigation. The 2001 report declares that one of its purposes is to re-examine previous oral testimony from representatives of the Irish tobacco industry (since they all refused to appear this time) 'in the light of subsequent revelation in the course of litigation in the United States' (Joint Committee on Health and Children 2001) and cites scientific reports from several other English-language countries as well as the WHO (see below).

\section{Diffusion and Policy Learning}

While policy learning/transfer/diffusion has frequently been cited as a formative influence on tobacco policy (Studlar 2002; 2005; Cairney 2009; Cairney et al. 2012), it is not always clear whether it provides some independent influence or is more of a reinforcement and rationale for policies largely determined by other sources ${ }^{11}$. While there may be some of the rationale motivation in Ireland as well, the consistency of citation in the relevant documents supports a strong case that policy learning through diffusion from other English-language countries as well as coercion and 
recommendations from the EU have been strong influences on policy development in Ireland over the years.

Underlying the concern about what international science says is a new, diffused way of thinking about its role in public health, often called 'the New Public Health', 'health promotion', or 'healthy public policy' (Leichter 1991; Studlar 2002; Cairney et al. 2012). Beginning in the 1970s, public health advocates and practitioners became more activist in orientation. Dissatisfied with a passive role in public policy, they became convinced that the path to healthier lives was to focus on prevention of noncommunicable diseases as well as communicable ones rather than on medical cures, and to help people lead such lives through better individual and group lifestyle practices. The foundation document of this movement was the Lalonde Report (named after the Health Minister), A New Perspective on the Health of Canadians (Health and Welfare Canada 1976), and its doctrines quickly spread across Western democracies. Tobacco was an early target for improving health outcomes through prevention, but other noncommunicable diseases have followed (Studlar 2014). Because it not only challenges traditional conceptions of curative medicine, but also impinges on people's individual decisionmaking about lifestyle choices, the New Public Health encounters political resistance to what some have called its 'secular morality' (Leichter 1991; Brandt and Rozin 1997; Studlar 2008). But especially in the realm of tobacco policy, the discoveries about the hazardous effects of secondhand smoke in the 1980s allowed the New Public Health to have an impact on policy. In Ireland this occurred in the series of reports highlighting tobacco consumption as a public health problem from the mid-1980s (see Table 2).

Reference to international experiences in tobacco policy, with implications for Ireland, are pervasive in legislative hearings and reports, government documents, and other commentary. For instance, Health - The Wider Dimension (1986) identifies smoking as a priority issue, based on evidence and perspectives adopted from Canada, $\mathrm{WHO}$, and the $\mathrm{EU}$, all jurisdictions focusing on the issue at that time. There are eight chapters in the 1999 report from the Oireachtas Committee (Joint Committee on Health and Children 1999), as follows:

1. Why the Committee Considered the Issue of Smoking

2. Smoking and Health

3. Smoking and Addiction

4. Tobacco Taxes and the Cost to the State of Tobacco Related IIInesses

5. The Legal Framework

6. The Manufacture, Sale and Distribution of Cigarettes in Ireland

7. Health Protection Promotion, Education and Smoking

8. A National Anti-Smoking Strategy.

Six of these eight chapters, all except 5 and 6 , contain references to US developments, usually multiple ones, that are considered relevant for Irish policy consideration, including US legislation, statements by US-based tobacco companies, research findings of the FDA and litigation and the subsequent released documents concerning tobacco industry knowledge of health hazards. Members of the 
committee visited four sites in North America: 1) Washington, DC, to consult members of the US Congress involved in tobacco hearings and legislation, the FDA, the Federal Trade Commission, the States' Attorney General's office; 2) Florida, to visit with officials involved in tobacco control policy; 3) New Orleans, to attend the annual Tobacco Litigation Conference; and 4) Ottawa, Canada, to speak with federal officials involved in tobacco control. Furthermore, included in the seven sources of evidence listed are these three: 1)'a substantial volume of documentation and reports obtained by the Committee during visits by members to the United States and Canada'; 2) WHO and World Bank publications; 3) information on the internet form the (US) House of Representatives Commerce Committee and its SubCommittee on Health and Environment (Joint Committee on Health and Children (1999: 2-3).

Towards a Tobacco Free Society: Report of the Tobacco Free Policy Review Group (2000) begins with an overview of five principles, referencing worldwide, WHO, European, and US (litigation revelations) developments. The research on smoking cited is mainly from the US, including US Surgeon General's reports and findings about the tobacco industry's knowledge of health hazards, especially addiction. Its extensive policy recommendations refer to the developing EU tobacco control agenda of the time for controlling advertising and product presentation as well as policy from the US, Australia, New Zealand, Canada, the United Kingdom, the WHO, and the World Bank. In 2003 the government borrowed a well-known slogan developed in Australia for a media campaign: 'Every cigarette is doing you damage' (Gilmore 2005: 124).

While more focused on the Irish experience, especially testimony from domestic witnesses (some of whom cited foreign evidence), the 2001 Oireachtas subcommittee report refers to research and policy in such English-speaking countries as the US, United Kingdom, New Zealand, Australia, and Canada, as well as to the EU and the WHO (Joint Committee on Health and Children 2001). At the 2001 subcommittee hearings, Tom Power, CEO of the newly-established Office of Tobacco Control, testified on relevance of international best practices for Ireland as well as the role of EU and WHO (Joint Committee on Health and Children 2001: 164).

In relation to best practices country-wide, we are obviously the national counterpart within WHO. We meet reasonably regularly and we discuss within WHO, Europe particularly, initiatives that are going on there. We also have extensive contacts through the United States and obviously with the European Union we have contacts there. And we are aware in the various practices that are involved in developing generally speaking, the ideas and measure proposed in the tobacco-free society report would be the ones perceived to be best practice at the moment.

Before the same committee, long time anti-tobacco campaigner and public health physician Fenton Howell cited reports from other countries on the dangers of second hand smoke (Joint Committee on Health and Children 2001). Howell and his 
fellow committee witness Luke Clancy were both medical doctors with extensive international knowledge. Earlier, an Irish Times article (Sheridan 2000), entered into the subcommittee's records, discussed evidence and policy from the US as part of the government's deliberations. The subcommittee report highlighted several research reports on second hand smoke issues as well as nicotine addiction, practically all of them from English-speaking countries or international organisations, as noted above.

However, once again developments in the USA dominated the deliberations. According to the Tobacco Atlas (Shafey et al. 2009), US litigation had revealed some 60,000 tobacco industry documents on Ireland, making it one of the top 25 countries in the world in this category. Yet relatively little research specifically has been cited from these documents in Irish legislative hearings and government documents, especially compared to US-relevant research. This is probably because the lack of tobacco research capacity in Ireland means that this evidence has remained underexplored, especially in relation to research on tobacco documents relating to larger countries having tobacco company headquarters, such as the US and UK. Before the subcommittee (Joint Committee on Health and Children 2001: 168), Tom Power of the OTC discussed the achievements of litigation in the US, especially in terms of revealing what the tobacco companies knew about topics such as disease risks, nicotine addiction, and youth smoking, and prospects for similar litigation in Ireland.

There was considerable enthusiasm for litigating against the tobacco companies for their contribution to health care costs in Ireland, a policy advocated by both Oireachtas committees (Joint Committee on Health and Children 1999; 2001), studied by the Irish Justice Department, and advocated by some visiting American attorneys, including one from the state of Minnesota Attorney General's office that litigated the case responsible for the largest worldwide release of tobacco company documents. ${ }^{12}$ But this particular policy instrument was never pursued. Eventually the Health department was persuaded by legal advice from the offices of the Attorney General and Chief State Solicitor that pursuing this route for would involve 'astronomical legal costs without any guarantee of success' for a small country (O'Brien 2011). While it would have been a difficult policy to pursue under Irish law, similar barriers did not prevent some Canadian provinces from changing their laws to allow litigation against tobacco companies, which has led to ongoing entanglements (Studlar 2002). ${ }^{13}$

Given the lack of public disclosure of the contents of documents relating to Irish-based tobacco companies, it is unknown how much evidence there was of company knowledge of health hazards. The publicly available documents from government investigations instead have argued that Irish companies were commercially allied with US ones and therefore must have had similar knowledge $(1999,2001)$. The refusal of the three Irish-based tobacco companies to testify before the committee is probably attributable to the threat of litigation, according to the letters they wrote the committee (sometimes from their lawyers), but it also prevented the committee from probing the information that the companies had. The only other general policy recommendation from the 2001 report not carried out by 2014 was to remove tobacco from the Consumer Price Index (CPI), but this would require agreement among EU members to implement. 
The US lacked a general, centrally-determined workplace smoking ban. Such a regulation through administrative order had been considered by the Occupational Health and Safety Administration (OSHA) in the early 1990s but had never been issued (Givel 2006). Through international contacts, Irish NGOs were aware of this debate and took lessons from it in helping to persuade political leaders to craft a similar regulation in Ireland (interviews). Eventually, the public Irish debate over the desirability and feasibility of a workplace smoking law hinged on a common evidence base, differently interpreted---and that base was previous non-smoking legislation for restaurants and bars in the United States! A stream of visitors came to the US, examined the situation primarily in New York City but also Boston and Washington, made pronouncements on site, and/or publicised their findings in Ireland. This included members of the Oireachtas subcommittee, Prime Minister Bertie Ahern, Health Minister Martin and supporting civil servants from the OTC, the IHIA, and Irish media. Other US academic specialists and political figures were brought to Ireland to present their views to the public (Gilmore 2005). James Repace, a US expert on the science of ventilation for cigarette smoke, was both a witness for the committee and a contributor to the Irish Times (Howell 2004; Read 2006). The findings of another US academic investigator, Stanton Glantz, who had examined the claims of job losses from a bar smoking ban in California, also were cited in Irish media (Gilmore 2005: 35). More generally, Gregory Connolly, who had led the tobacco control program in the state of Massachusetts, continued his visits to Ireland to promote the smoking ban (Connolly and McGoldrick 2003; interviews). Jeffrey Wigand, the famous US tobacco company whistle-blower, also voiced his support in the Irish media for the workplace smoking ban (Gilmore 2005).

The inspirational predecessors of the 2004 act were only in US jurisdictions and to a much lesser extent Canada (Gilmore 2005: 27; Currie and Clancy 2010); none were in Europe although Norway and Sweden followed with indoor nonsmoking bans soon thereafter. Ireland's successful example served as a model for several other countries within and without the EU to emulate. Irish government officials encouraged this lesson drawing (Gilmore 2005: 157-158).

The Health Service Executive (HSE) (2010: 9) framework document to guide Ireland's tobacco control policy for the next few years not only adopted the MPOWER model from the WHO (it noted that similar recommendations had been made by the World Bank and the US Department of Health and Human Services) but also listed among its principles 'review best practice in terms of tobacco control nationally and internationally with particular reference to how the HSE can develop national standards'.

The debate at the end of the 2000s over the role of high taxes in smuggling and lost revenue (Jennings 2011; Reidy and Walsh 2011) also featured analyses based on the experience of other countries, One of these studies was from US economists (Chaloupka and Tauras 2011), the other by a UK-based one (Reed 2011). While all of these analyses referenced international studies, the one by Reed was especially prolific in citing findings on this issue from California in the US, New Zealand, Australia, Spain, and Italy as well as the UK.

\section{Tobacco Free Ireland: Report of the Tobacco Policy Review Group (2013)} focusses on 'international best practice' in research and policy, focusing particularly 
on the EU and the WHO. Australia was the pioneer in plain packaging, and Ireland has been in close touch with the relevant government offices there in developing its own proposal. Thus far it is only English-speaking countries that have seriously considered plain packaging as a policy tool (Canada, Australia, New Zealand, UK, and Ireland).

Unlike earlier reports, the 2013 document does not dwell on US data and policy. It does not even mention the US specifically in the discussion of under-age test purchases of cigarettes even though this technique was pioneered there (previously cited as coming from the US -Joint Committee on Health and Children 1999). Based on its own successful development of policy over the past decade, there also are more self-references, reflecting less need for external lesson drawing.

\section{Comparative Analysis: Ireland's Tobacco Policy in Space and Time}

\section{(Table 3 about here.)}

Broadly, Ireland's development of tobacco policy instruments and calibrations over time has coincided with those introduced contemporaneously in other Western democracies (Studlar and Cairney 2014). See Table 3. Aside from early outliers such as age restrictions (rarely enforced), food preparation restrictions, and high taxes, the years of 'regulatory hesitancy' brought broadcast advertising bans, restrictions on other advertising, minimum pricing, and health warnings on packages. Perhaps because of limited resources in a small country, Ireland was slow in education and especially cessation, not developing these until the 1990s. It was, however, the second country in the world to have rotating health warnings. In the 1980s the second hand smoke findings ushered in more restrictions, including nonsmoking indoor public areas, government reports, cigarette content restrictions, and several other limitations on advertising and sales. The EU facilitated regulation in some of these areas, and Ireland became part of the group of countries arguing for stronger tobacco control in EU councils.

Interestingly, Ireland abandoned voluntary agreements with the tobacco industry early, in contrast to some other English-speaking countries such as the United Kingdom, Canada, and New Zealand. The later voluntary agreement on nonsmoking areas was with merchants rather than the industry itself although the latter may have encouraged them. Starting in the late 1990s Ireland became more aggressive, most notably in the workplace smoking ban but also in moving to a complete advertising and promotion ban (even in the wake of the temporary defeat of the Tobacco Products Directive in the ECJ) and an array of new and stronger measures that Studlar and Cairney (2014) find to be typical of Western democracies in the late 1990 s and early 2000 s (see Table 3 ), including raising the age limits, restrictions on package size and vending machine sales, a comprehensive strategy raising taxes explicitly for public health (once), and eventually pictorial warnings and projected plain packaging. Ireland stayed ahead of the UK in all comparative 
rankings until the UK 'policy surge' of the mid-2000s led it to go ahead for the top spot later in that decade (Joossens and Raw 2006; 2008). Not only did the EU surpass the UK as a reference point for policy, but research and policy developments elsewhere in the English-speaking world, especially the United States, served not only as a source of inspiration but close policy emulation (Rose 2005).

While the 2004 workplace smoking ban, especially as it affected traditional 'pub culture', put Ireland on the tobacco control 'map', Ireland's policies were relatively restrictionist from the 1970s in instruments such as broadcast bans, rotating warning labels, minimum pricing, and advertising restrictions (Roemer 1982; 1993; Hiilamo et al. 2012), and they have consistently ranked among the stronger ones in Europe and in the world. Studlar et al. (2011) show that, for 17 different instruments across five policy dimensions (advertising and promotion, sales, nonsmoking areas, cessation, and public education) in the period 1986-2007, Ireland consistently ranked in the top third of the 'old 15' EU member countries. This rating does not even include its consistently high taxes. In non-tax tobacco policies Ireland ranked third overall in 1986, second in the late 1980s, and then gradually declined in the 1990s until it was seventh in 1999. Under pressure from the EU, other countries leapfrogged Ireland in 1990s despite the country's incremental progress. But then the 'policy surge' of the early 2000s put it back into the top five and eventually the top two, as confirmed by its ratings in the public health 'tobacco control scale' (including taxes) across almost 30 European countries, 2005-2013 (Joossens and Raw, 2005; 2006; 2007; 2008; 2011; 2014).

In another overtime analysis, Currie (2013a) compares Ireland to ten other European countries, projecting the dimensions of the 'expert opinion' Joossens-Raw scale back to 1950. She utilises four policies (non-smoking areas, advertising and promotion, health warnings, and cessation support) and finds a similar pattern to Studlar et al. (2011) with some variations. Ireland made consistent incremental progress in the 1990s and early 2000s, but then doubled its score in 2004 to become the European leader until 2007 when the United Kingdom exceeded it. Thus the workplace smoking ban built upon a previous foundation of policies rather than being a complete departure.

The Irish government recently adopted the WHO 2008 MPOWER model of six policies--non-smoking areas, cessation, health warnings, mass media campaigns, advertising and promotion, and taxes (Health Executive 2010; 2013). Currie (2013b) and Currie and Gilmore (2013) have evaluated Ireland's tobacco policy to this standard, focusing on effects on prevalence, morbidity, and mortality. Currie and Gilmore (2013) confirm that Ireland remains one of the highest-ranked tobacco control regimes in Europe. Since its ratings on other health indicators for a wide variety of conditions (including alcohol, food and nutrition, fertility, pregnancy and childbirth, children's health, infectious diseases, hypertension, cancer screening, mental health, road traffic deaths, and air pollution) puts it overall in the second, 
middle group of counties (Mackenbach and McKee 2013), its tobacco policy standing is exceptional in both overall health policy and country comparisons.

In contrast to the impression gained from the 'shock' workplace smoking ban announcement in 2003, the pace of Irish tobacco policy has been deliberate and consistent. The 2004 countrywide workplace ban may have brought Ireland international intention, but it is often among the early adopters, as on broadcast bans, rotating health warnings, minimum pricing, limitation of advertising budgets, the smokeless prohibition, pictorial warnings, and, if current plans are realised, plain packaging. Furthermore, the Irish legislative process can be misunderstood, as broad legislation empowering the health minister to enact later, more detailed regulations is the norm. Thus the rollout of policies over the first decade of the 2000s has been the product of legislation first passed in 2000, 2002, and 2004.

In a website list of its functions, the Office of Tobacco Control (http:www.otc.ie/about_us.asp) lists as the second one: To consult with relevant national and international bodies on developments in tobacco control. This is true for NGOs as well as government bodies. As noted previously, within the EU, Ireland has usually been a leader rather than a follower in tobacco policy. Overall, it may be fair to say that on some issues Ireland and the EU have leapfrogged each other in adopting restrictive tobacco policies, but on others the EU has acted as a restraint on Ireland. The EU has been only one source, however, in a concerted lesson-drawing effort by Ireland in considering the adoption of its own policies. While Ireland has been embedded in within the EU for several of its policies, it also has sought guidance in research and policy from the wider world, especially its fellow Englishspeaking countries, several of whom are among the recognised leaders in tobacco control, such as Australia, Canada, New Zealand, and the United States, plus, more recently, the United Kingdom (Wilensky 2002; Studlar 2002; 2005; 2007; Marmor and Lieberman 2004; Cairney et al. 2012). Today Ireland is less in need of EU stimulus for its tobacco policies.

From the early 2000s, Ireland's policies look very much as US policies would have if the US central government had been able to act on its own research. However, cases of blockage in the US policy process included OSHA's failure to issue a workplace non-smoking regulation in the mid-1990s, the 1998 defeat of the Global Settlement' in Congress, and the Supreme Court's rejection of the FDA's attempt to regulate tobacco in $2000^{14}$. Aside from litigation, Ireland, with a less complicated policy process involving fewer veto points than the US (Stepan and Linz 2011), managed to use US-developed evidence and policy instruments to produce a more comprehensive, centrally-determined tobacco policy than the country that was its major source of emulation. While US policy and research has continued to be important, its high tide of influence was in the 1998-2004 period.

\section{Conclusions}

Tobacco policy in Ireland has been analysed using the five-factor model of Cairney et al (2012). The Irish case fits this model well. The agenda of tobacco policy has changed in line with the general periods of Western democratic countries, but Ireland has always been among the more restrictionist countries for its time. At a key juncture in policy development, committed political entrepreneurs seized the 
opportunity of supportive if passive public opinion to push a stronger regulatory agenda forward by redefining the issue. Socioeconomic forces have become more favourable for control measures to be adopted. While two contending policy networks have contested policy, over time the health lobby has come to dominate the tobacco agenda and policy. Irish institutions have played a role in this. As a parliamentary democracy, the interaction between the legislature and executive is the key relationship. Tobacco policy has not been a partisan issue, and proposed policies have generated considerable consensus in the legislature while allowing the executive to have discretion in timing and enforcement. The civil service has become more capable in terms of policy advice and enforcement. While Ireland has had little research capacity of its own in this field, it has relied heavily on scientific and legal research from other countries, principally the United States and other English-language countries. Similarly, it has been willing to adopt policies first tried in other jurisdictions.

What differentiates Ireland somewhat from other cases is the clear importance of international attentiveness and policy diffusion. Over time, implementation and enforcement of tobacco policies may have been slow, and there has been continuing tension between the finance and health departments. Ireland is a small country without native leaf growing or export-oriented manufacturing. Embedded in the English-speaking world, the EU, and the WHO, Ireland has been willing to get lessons from abroad. It also has become of the strongest proponents of more restrictive tobacco control within the EU. Lacking much of a research capacity of its own, it has relied heavily on foreign information and perspectives, especially the 1994 framing by the USFDA of tobacco addiction encouraged in youth, findings about tobacco company knowledge of health hazards revealed by US court cases, and policies tried in other jurisdictions.

Ireland's overall policy learning/transfer process was a form of 'hybridisation' (Rose 2005; Marsh and Sharman 2009), combining elements of programmes with the same objectives from different jurisdictions. As indicated previously, different jurisdictions have come to the fore at different times, but, aside from the EU and the WHO, they have been overwhelmingly English-speaking ones, especially the USA. There has been a persistent voluntary reliance on the US, especially in considering the workplace smoking ban, and, by necessity, on the EU. Ireland clearly sought, across institutions such as the executive and legislature as well as through NGOs and the media, to base its policy upon research findings in other countries, principally the US, as well as policies adopted in other jurisdictions, again mainly those in the US. This was done on a 'demand' basis in Ireland, making use of existing research and policy innovations elsewhere. While overall this became hybridization, the approach Ireland took on specific policies was what Rose (2005) calls 'adaptation', 'altering the detail of the design of a programme elsewhere without removing major elements'. The only policies that Ireland had to adopt were from EU directives. However, it was often ahead of the EU in adopting policies, helped shape these directives in EU organisations, was usually quick to implement them, and continued with its banning of advertising even when TAD1 was in jeopardy. ${ }^{15}$ 
While Ireland was attentive to evidence and policy developments in several countries, it paid the closest attention to the United States. Even though the US on a countrywide basis has had a rather fragmented policy, it a bastion of research on smoking, has had some state and local-level jurisdictions with strongly restrictionist policies, and litigation there has revealed a plethora of tobacco industry documents relating to other countries as well (Cairney et al. 2012). The English language and strong cultural ties between Ireland and the US facilitated this process. Otherwise, one might think that more appropriate comparisons for Ireland would be strong tobacco control countries of approximately similar size, such as Norway (also subject to EU law as a European Economic Area member) and New Zealand, a fellow English-speaking country. Tobacco policies in the latter, however, tend to follow those adopted by Australia (Studlar 2005), and neither of these had a work place smoking ban in place during the most intense period of Irish policy development at the turn of the twenty-first century.

Ireland is a clear case in which policy learning in the form of transfer/diffusion has played a large role. Lacking its own strong research and policy development capacity, the government has looked to external sources to provide stimulus, inspiration, and models of policy. This first occurred through the legislative branch, which, acting upon the information and attitudes provided by anti-tobacco policy networks and a receptive public, questioned existing government policy and its implementation, investigated alternatives, and made strong, consensual policy recommendations. The Irish NGO community, the legislature, and the government have all unashamedly relied on evidence and policy from abroad, especially from English-language sources, primarily the US, in developing Irish tobacco policy. There is no rhetorical cover of 'made in Ireland' as one encounters, for instance, in some Canadian policy formulations that rely heavily on evidence and policy from abroad, especially the US (Studlar 2002).

Diffusion has been recognised as an influence on tobacco policy in previous studies of tobacco policy elsewhere in the world (Studlar 2002; 2005; 2009; Hiilamo et al. 2012; Cairney et al. 2012). As Hiilamo et al. (2012) argue, the tobacco industry made use of its globalised knowledge to try to block the spread of stronger health warning labels. But the case of Ireland clearly shows that diffusion is also a process that NGOs and government institutions, even (or perhaps especially) in a small but well-connected country can use to enhance their own policies and make them a leading tobacco control jurisdiction in the world. 
Table 1: Eras of Tobacco Control in Western Democratic Countries

\begin{tabular}{|l|l|l|}
\hline \multicolumn{2}{|c|}{ Period } & \multicolumn{2}{|c|}{ Theme } \\
\hline Paradigm: Tobacco Promotion (Political Economy) \\
\hline $\begin{array}{l}\text { Phase 1: 1885- } \\
1914\end{array}$ & $\begin{array}{l}\text { Consolidation of the Cigarette Industry and Early } \\
\text { Controversies over Morality and Public Health }\end{array}$ \\
\hline $\begin{array}{l}\text { Phase 2: 1914- } \\
1950\end{array}$ & $\begin{array}{l}\text { Tobacco Growing and Manufacturing Promoted by } \\
\text { Governments }\end{array}$ \\
\hline $\begin{array}{l}\text { Phase 3: 1950- } \\
1964\end{array}$ & The Gathering Storm of Health Concerns \\
\hline Paradigm: Tobacco Restriction (Public Health, Secular Morality) \\
\hline $\begin{array}{l}\text { Phase 4: 1964- } \\
1985\end{array}$ & Regulatory Hesitancy \\
\hline $\begin{array}{l}\text { Phase 5: 1985- } \\
2014\end{array}$ & Tobacco as Social and Global Menace \\
\hline $\begin{array}{l}\text { Phase 6: Currently } \\
\text { developing }\end{array}$ & Neo-prohibitionism vs. Harm Reduction \\
\hline
\end{tabular}

Source: Adapted from Studlar 2002; Cairney et al. 2012 
Table 2: Government and NGO Reports with Reduced Smoking as a Goal (excluding legislation)

1986: Health - The Wider Dimension

1987: Promoting Health through Public Policy

1994: Shaping a healthier future

1996: National Cancer Strategy

1999: Building Healthier Hearts

2000: National Health Promotion Strategy

2000: Towards a tobacco free society

2001: Quality and Fairness

2006: A Strategy for Cancer Control in Ireland

2008: Tackling Chronic Disease

2010: HSE Report: National Cardiovascular Health Policy

2013: Healthy Ireland

2013: Tobacco Policy Review Group Report 
Table 3: Sequencing of Tobacco Control Policy Instruments in Western Democracies

\begin{tabular}{|l|}
\hline Pre-1980s (6) \\
\hline 1) Increases in taxation for revenues \\
\hline 2) Age limits for purchase and possession (some countries) \\
\hline 3) Educational campaigns \\
\hline 4) Health warnings on packages \\
\hline 5) Broadcast advertising limits \\
\hline 6) Limited smoking venues for safety reasons and in major carrier public \\
transportation (buses, subways, trains) \\
\hline 1980s (9) \\
\hline 7) Cessation services \\
\hline 8) Capacity building for local governments and anti-tobacco organizations (selected \\
jurisdictions) \\
\hline 9) Broader advertising limits \\
\hline 10) Limits on smoking in more mass public venues, private and government \\
\hline 11) Government reports \\
\hline 12) Cigarette contents restricted \\
\hline 13) Airlines Restricted \\
\hline 14) Promotions restricted \\
\hline 15) Stronger health warnings (multiple, rotating) \\
\hline 1990s (8) \\
\hline 16) Taxation for public health \\
\hline 17) Raising the age limit for cigarette purchase \\
\hline 18) Bans on smoking in government venues \\
\hline 19) Limits on package size \\
\hline 20) Restrictions on vending machines \\
\hline 21) Bans on smoking in private hospitality venues \\
\hline 22) Comprehensive government strategy \\
\hline 23) Restrictions on point of sale advertising \\
\hline 2000s (1) \\
\hline 24) Pictorial health warnings \\
25) Plain packaging \\
26) Bans on sweeteners in cigarettes \\
27) Restrictions on e-cigarettes \\
\hline
\end{tabular}

\section{Source: Adapted from Studlar and Cairney (2014)}




\section{Appendix: Developments in Tobacco Policy in Ireland 1908-2014}

1908 UK Children Act--no sales to under-16s (carried over to independent Ireland) 1947 Health Act empowers Minister to regulate for health and safety 1950 Health Act (Food Hygiene Regulations) bans of smoking in food preparation and storage areas

1960 Abolition of retail tobacco licencing, effective 1961

1964 Voluntary code on advertising

1971 Tobacco advertising banned on television.

1972 VAT Act levies this tax on tobacco products

1977 Finance (Excise Duty on Tobacco Products) Act imposed excise tax on tobacco and licenced tobacco manufacturers

Repeal of provision that only tobacco allowed in cigarettes.

1978 The Tobacco Products (Control of Advertising, Sponsorship and Sales

Promotion)

Act banned advertising on radio, restricted it in newspapers and billboards; gave health minister broad powers over tobacco promotion, including discounts

1979 Tobacco Products (Control of Advertising, Sponsorship and Sales Promotion) Regulations implemented above powers, including three rotating warnings on side of cigarette packs (second country in world to have rotating warnings, implemented 1980;

discount pricing banned (minimum unit pricing); marketing incentives banned

Tobacco advertising and sponsorship expenditures for 1980 capped at previous year's level+inflation, a policy that continued in later legislation

1985 Health (Restricted Article) Order, making tobacco product commercial transactions subject to licensing by the state.

Europe Against Cancer Programme launched informally (1987 formally)

1986 Tobacco Products (Control of Advertising, Sponsorship and Sales Promotion)

Regulations provided for rotating health warnings on front and back of packs;

advertising banned in shop fronts, effective 1987

Promoting Health through Public Policy, first Irish government statement on Healthy

Public Policy, including tobacco control prominently

1987 Air Pollution Act 1987 (Marketing, Sale and Distribution of Fuels) Regulations banned use of bituminous coal in urban areas

1988 Tobacco (Health Promotion and Protection) Act banned the sale of tobacco to under-16s, vending machine venues restricted, banned packages of less than 10 , banned sale of smokeless tobacco products (perhaps first in the world), and allowed the Health Minister to restrict smoking in government buildings, indoor public entertainment, health premises, schools, and public transportation (Minister did not exercise this power); ingredient restrictions

1989 EU Labelling Directive mandates health warnings on cigarettes

EU Advertising Directive bans TV advertising and sponsorship

EU Resolution on smoking in public policies recommends smoke-free environments First Health Unit media campaign

1990 Tobacco (Health Promotion and Protection) Regulations gave effect to 1988 legislation;

EU Tar yield Directive

1991 Tobacco Products (Control of Advertising, Sponsorship and Sales Promotion) Regulations limited point of sale advertising to print only, and banned in publications primarily aimed at under18s; sponsorship restricted; implemented advertising and 
sponsorship expenditure limits; continued to ban discounts; legislated EU-approved health warnings on front and back of tobacco products and EU-approved labelling of ingredients on packs

ASH founded as anti-tobacco lobbying group by Irish Cancer Society (ICS) and Irish Heart Foundation (IHF)

Legislated 1990 EU regulations on maximum tar yields (implemented from 1992)

1992 Limited network of partially reimbursed cessation services

EU Labelling Directive covering health warnings on non-cigarette products, banned smokeless oral products

EU Tax Directive (harmonisation)

EU Council Resolution recommends measures to combat smoking

1993 Government Health Promotion Unit media campaign

Maastricht Treaty expands EU role in health

1994 Tobacco Products (Control of Advertising, Sponsorship and Sales Promotion)

(Amendment) Regulations required rotating warnings on tobacco products other than cigarettes, implementing 1992 EU legislation

Shaping a Healthier Future - A Strategy for 1990s' set targets for reduction in prevalence; other reports follow

Smoking Target Action Group (STAG) established to co-ordinate work towards achieving the reduction in smoking levels targeted in the National Health Strategy of 1994.

Voluntary code among government, NGOs, employers, and trade unions for nonsmoking in indoor areas

Health Promotion Unit Anti-tobacco programs in schools

Health Promotion Unit and Health Boards subsidize ICS and IHF anti-tobacco campaigns

1995 Tobacco (Health Promotion and Protection) Regulations mandated nonsmoking areas in govt. and public buildings, limited to $1 / 3$ of airline seating, but not in all workplaces, effective 1996

New government media campaign

EU Tax Directive

1996 International Civil Aviation Organisation smoking agreement takes effect; Irish airlines ban smoking voluntarily

Tobacco Products Act (Control of Advertising, Sponsorship and Sales Promotion)

Regulations reduced advertising and sponsorship expenditures

EU Council Resolution recommends measures to combat smoking

1997 The Irish Cancer Society established the 'Quitline' service, later supported by HSE

EU Tobacco Advertising Directive bans advertising in press, radio, and internet Joint Oireachtas Committee on Health and Children established

1998 New government media campaign

Oireachtas decides on a comprehensive review of tobacco health policy

EU Tobacco Advertising Directive bans sponsorship with cross-border effects

1999 The Department of Health and Children published Building Healthier Hearts, a national strategy for dealing with heart disease, esp. on cessation support. The Oireachtas Joint Committee on Health and Children published $A$ National Anti-smoking Strategy - A Report on Health and Smoking, with a proposed comprehensive list of measures, including a proposed workplace smoking ban. Budget increase of 50 pence (64 cents) on the price of a packet of cigarettes (16\% increase) to help fund Building Healthier Hearts—only dedicated tax funding for TC 
EU Council resolution recommends measures to combat smoking

2000 The Tobacco Free Policy Review Group published their report on implementing the Oireachtas report Towards a Tobacco Free Society, the first official government. tobacco control strategy

Tobacco Products (Control of Advertising, Sponsorship and Sales Promotion)

Regulations bans all advertising in print media other than limited retail and trade advertising. Sponsorship by tobacco companies limited; Office of Tobacco Control authorised (est. 2001)

Tax increase

New media campaign

Health (Miscellaneous) Amendment Bill, 2000-increase sales limit to 18

ECJ annuls 1998 TAD1

2001 Joint Oireachtas subcommittee on Health and Children hearing and published report, calling for ban on workplace smoking

Research Institute for a Tobacco-Free Society authorized (est. 2004)

Partial health coverage for cessation treatment

Tax increase

OTC sponsors seminar with international experts on second hand smoke hazards

US Minnesota Assistant Attorney General visits Ireland to discuss litigation against tobacco companies

EU Tobacco Product Regulation Directive requires warnings and reporting of ingredients to governments, bans deceptive descriptors, limits tar, nicotine, and carbon monoxide

2002 The Public Health (Tobacco Act), 2002 extended advertising ban to sponsorship and indirect marketing, including giveaways and promotional discounts No tobacco sales to under-18s (not implemented until 2007); Health Minister given broad authority to regulate smoking places

Government proposes smoking ban in restaurants and food-serving pubs.

Increased size for EU-mandated health warnings.

Tax increase

EU Tax Directive

OTC and Health and Safety Authority report, The Health Effects of Environmental Tobacco Smoke in the Workplace, reviews international evidence and supports workplace smoking ban (first Irish report on second hand smoke, $20^{\text {th }}$ in the world since 1986))

2003 Framework Convention on Tobacco Control (FCTC) adopted

EU Tobacco Products Directive transposed into Irish Law, setting out nicotine and tar levels and imposing restrictions on the colour font of tobacco advertising on products as well as setting a minimum (larger) size for health warnings

Government proposes workplace smoking ban

New media campaign.

Quitline expanded and supported by HSE

EU Tax Directive

Revised EU Tobacco Advertising Directive bans all forms of audiovisual communication for tobacco products, including telecast, and internet ad and sponsorship; graphic warning labels as option

EU Council Recommendation on the prevention of smoking and on initiatives to improve tobacco control

2004 The Public Health (Tobacco) (Amendment) Act 2004 (Commencement) Order replaced the previously proposed ministerial regulations and enacted a general 
indoor workplace smoking ban, including offices, bars, pubs, and all public transportation; vending machines restricted; also bans on advertising in cinema, billboards and print, with certain exceptions; ban on all indirect advertising (Currie 2013)

Party to EU agreement with Philip Morris Inc. to combat smuggling (others in 2007 and 2010)

Ireland hosted an EU Conference on 'Future Directions in Tobacco Control'

2005 No tax increase on cigarettes for the first time in 26 years

The Irish government ratified the FCTC.

International sponsorship and indirect advertising banned, following TAD2

Reduced media campaign, also EU campaign

2006 The High Court supported using children to test purchase cigarettes in retail outlets.

An EU Court of Justice decision ensures payment of domestic custom duties when buying tobacco products in another EU country

No tax increase

2007 Tobacco companies discontinued their legal challenge to key provisions of the Public Health (Tobacco) Acts 2002 and 2004.

Sections 38(1) and 38(3) of the Public Health (Tobacco) Acts 2002 to 2004 enforced, banning the sale of cigarettes in unpacked or in packets of less than 20 and 'candy cigarettes'

Hospitals and health services adopt tougher smoking limitation regulations

Tax increase,

EU Tobacco Advertising Directive bans internet sales

2008 Guidelines for Tobacco Management in the Mental Health Setting in HSE.

High court decision on dual language health warnings (Irish and English) on tobacco products leads to larger health warnings.

Public consultation takes place on graphic pictorial warnings.

Tax increase,

Legislation bans internet sales in compliance with EU TAD 2007

Legislation allows citizens from new EU member states to import cigarettes

purchased abroad for personal use

2009 First smokefree hospital campuses

Public Health (Tobacco) Act: No point of sale advertising or display of tobacco

products permitted in retail; self-service vending machines are prohibited except in

licensed premises; all retailers selling tobacco must register with the OTC

HSE CEO signed Tobacco Free United (TFU) Charter, appealing to all health care professionals to encourage cessation.

New media campaign

Irish tobacco companies initiate proceedings in High Court against point of sale and display ban

EU Council Recommendation on smoke-free environments and other supportive measures

Tax increase

2010 Health Service Executive Framework

Public Health Tobacco (Amendment) Act dissolves OTC and transfers staff and functions to Health Service Executive

ECJ decision overrules Ireland's minimum price for cigarettes as violation of 1995

EU Tax Directive

Workshop for tobacco control stakeholder groups 
Appointment of Tobacco Policy Review Group

No tax increase

2011 Graphic health warnings announced by Health Minister

New media campaign

No tax increase

Office of Revenue Commissioners produces Strategy on Combating the Illicit

Tobacco Trade 2011-2013

National Tobacco Control Office (NTCO) replaced Office of Tobacco

Control under the Public Health (Tobacco) (Amendment) Act 2010.

EU approves fire-safe (reduced ignition propensity, RIP) cigarettes only

2012 Health minister supports Private Member's bill to ban smoking in cars with children

New media campaign

FCTC Protocol to Eliminate the Illicit Trade in Tobacco Products agreed by

Conference

of Parties

2013 Government introduces Public Health (Tobacco) (Amendment) Bill to maintain power of Health Minister to ban discount pricing despite EU ban on minimum pricing

Seanad Public Consultation Committee recommends stronger tobacco control measures

Health Minister announces regulations for pictorial health warnings on packages

Healthy Ireland-A Framework for Improved Health and Wellbeing 2013-2025

Ireland holds Presidency of EU Council of Ministers for first six months of year, highest health priority is supporting Commission's revised TPD; Prime Minister encourages Irish Euro MPs to vote for strongest new TPD

$2^{\text {nd }}$ Tobacco Control Strategy announced, in which Ireland and tobacco will be 'denormalised'; measures to be introduced include plain packaging, licensing of tobacco retailers, and following EU recommendations on e-cigarette regulation

Seanad Private Members' Bill to ban tobacco company lobbying of government introduced, debated, and defeated

Tax increase

2014 Government introduces bill to prohibit smoking in cars with children

New EU Tobacco Products Directive

Royal College of Physicians of Ireland establishes Tobacco Control Policy Group Tax increase

2015 HSE target for smoke-free campuses

Sources: Health Service Executive (2010); Currie et al. 2013; Joint Committee on Health and Children (1999); Tobacco Free Ireland: Report of the Tobacco Policy Review Group. (2013), 


\section{References}

Albæk, E., Green-Pedersen, C. and Nielsen, L.B. (2007) Making Tobacco Control a Political Issue in the United States and Denmark: The Dynamics of Issue Expansion in Comparative Perspective. Journal of Comparative Policy Research 9 (1): 190-218.

Allwright, S., McLoughlin, J.P., Murphy, D., Pratt, I., Ryan, M.P. and Smith, A. (2002) Report on the Health Effects of Environmental Tobacco Smoke (ETS) in the Workplace (Dublin: Office of Tobacco Control/health and Safety Authority).

Asare, B., Cairney P. and Studlar D.T. (2009) Federalism and Multilevel Governance in Tobacco Policy: The European Union, the United Kingdom, and UK Devolved Institutions. Journal of Public Policy 29 (1): 79-102.

Baggott, R. (1988) Health vs. Wealth: the politics of smoking in Norway and the UK. (Glasgow: Centre for Public Policy, Papers in Comparative Politics).

Barry, J. (2005) Editorial: Ireland's Workplace Smoking Ban. Drugs, Education, Prevention and Policy 12 (1):1-4.

Baumgartner F. R. and Jones B. D. (1993) Agendas and Instability in American Politics. Chicago: Chicago University Press.

Bayer, R. and Colgrove, J. (2004) Children and Bystanders First: The Ethics and Politics of Tobacco Control in the United States, in: L. Feldman and R. Bayer (Eds) Unfiltered: Conflicts over Tobacco Policy and Public Health, pp. 8-37 (Cambridge: Harvard University Press).

Beesley, A. (2014) US business lobbies urge Kenny to rethink tobacco packaging. Irish Times 5 April. http://www.irishtimes.com/news/politics/us-business-lobbiesurge-kenny-to-rethink-tobacco-packaging-1.1751038

Börzel, T.A. (2002) Pace-setting, Foot-dragging, and Fence-sitting: Member State Responses to Europeanization. Journal of Common Market Studies 40 (2): 193-214.

Bowers, F. (2003) Review of the year. Irishhealth.com 1 January http://www.irishhealth.com/article.html?id=4514

Brandt, A.M. and Rozin, P. (1997). Introduction, in: A.M. Brandt and P. Rozin (Eds), Morality and Health (New York: Routledge).

Cairney, P. (2009) A 'Multiple Lenses' Approach to Policy Change: The Case of Tobacco Policy in the UK. British Politics 2 (1): 45-68.

Cairney P., Studlar D.T. and Mamudu H. (2012) Global Tobacco Control: Power, Policy, Governance, and Transfer (London and New York: Palgrave-Macmillan).

Castles, F. (Ed.) (1993) Families of Nations (Brookfield, NH: Dartmouth). 
Castles, F. and Obinger, H. (2008) Worlds, Families, Regimes: Country Clusters in European and OECD Area Public Policy. West European Politics 31(3): 321-344.

Chaloupka, F.J. and Tauras, J.A. (2011) The Demand for Cigarettes in Ireland. (Dublin: Health Service Executive, National Tobacco Control Office).

Chari, R. and Bernhagen, P. (2011) Financial and Economic Crisis: Explaining the Sunset over the Celtic Tiger. Irish Political Studies 26 (4): 473-488

DOI: 10.1080/07907184.2011.619736

Connolly, G. and McGoldrick, D. (2003) USA: when Irish eyes are smarting. Tobacco Control 12:248-249 doi:10.1136/tc.12.3.248

Cunningham, R. (1996) The Canadian Tobacco War (Ottawa: IDRC).

Currie, L.M. (2013a) Appendix A: Tobacco Control Index in: L. Nguyen, G. Rosenquist, and M. Pekurinhen. Demand for Tobacco in Europe: An Econometric Analysis of 11 Countries for the PPACTE PROJECT (Helsinki: National Institute for Health and Welfare).

Currie, L.M. (2013b) Public Policy and Health Behaviour: An Investigation of Tobacco Control Policy and Smoking in Ireland. (Unpublished Ph.D. dissertation, Royal College of Surgeons Ireland).

Currie, L.M. and Clancy, L. (2010) The Road to Smoke-Free Legislation in Ireland. Addiction 106 (1): 15-24.

Currie, L.M., Blackmon, K., Clancy, L. and Levy, D.T. (2013) The effect of tobacco control policies on smoking prevalence and smoking-attributable deaths in Ireland using the IrelandSS simulation model. Tobacco Control 22:e25-e32

doi:10.1136/tobaccocontrol-2011-050248

Currie, L. and Gilmore, A.M. (2013) Tobacco Control, in: J.P. Mackenbach and M. McKee (Eds) Successes and Failures in Health Policy in Europe: Four Decades of Divergent Trends and Converging Challenges, pp.23-40 (Maidenhead: Open University Press).

Currie, L, Townsend, J., Leon Roux, M., Godfrey, F., Gallus, S., Gilmore, A.B., Levy, D., Nguyen, L., Rosenqvist, G. and Clancy, L. (2012) Policy Recommendations for Tobacco Taxation in the European Union: Integrated Findings from the PPACTE Project. (Dublin: The PPACTE Consortium).

De Francesco, F. (2013) Transnational Policy Innovation: the OECD and the diffusion of regulatory impact analysis (Essex: ECPR Press).

Doll R. (1998) The First Reports on Smoking and Health, in: S. Lock, L. Reynolds, and E.M.Tansey (Eds) Ashes to Ashes: The History of Smoking and Health. (Amsterdam: Rodopi).

Duina, L. and Kurzer, P. (2004) Smoke in Your Eyes: The Struggle over Tobacco 
Control in the European Union. Journal of European Public Policy 11 (1): 57-77.

Eurobarometer.(2012).

http://ec.europa.eu/health/tobacco/eurobarometers/index en.htm. Accessed 8 February 2014.

European Commission (1982) Actions against Smoking in the Member States of the European Community (Report EUR 7531. Brussels and Luxembourg: DirectorateGeneral for Employment, Social Affairs and Education, Direction Health and Safety).

European Commission (2004) Tobacco or Health in the European Union: Past, Present and Future (Luxembourg: Office for Official Publications of the European Commission).

Faid, M. and Gleicher, D. (2011) Dancing the Tango: The Experience and Roles of the European Union in Relation to the Framework Convention on Tobacco Control. (Geneva: Graduate Institute, Global Health Programme).

Farquharson, K. (2004) Influencing Policy Transnationally: Pro- and Anti-Tobacco Global Advocacy Networks. Australian Journal of Public Administration 64 (1): 80-92.

Fong, G.T., Hyland, A., Borland, R., Hammond, D., Hastings, G., McNeill, A., Anderson, S., Cummings, K.M., Allwright, S., Mulcachy, M., Howell, F., Clancy, L., Thompson, M.E., Connolly, G. and Driezen, P. (2006) Reduction in tobacco smoke pollution and increases in support for smoke-free places following the implementation of comprehensive smoke-free workplace legislation in Republic of Ireland: findings from the ITC Ireland/UK survey. Tobacco Control 15 (suppl. 3): 5158.

Gilmore, N. (2005) Clearing the Air: The Battle over the Smoking Ban (Dublin: Liberties Press).

Givel, M. (2006) Neoliberal and public health impact of not adopting OSHA's proposed national secondhand tobacco smoke rule. International Journal of Health Services 36 (1): 137-155.

Government to press ahead with ban on smoking in cars (2014) thejournal.ie http://www.thejournal.ie/ban-smoking-cars-children-ireland-laws-501082Jun2012/?utm source=shortlink

Guigner, S. (2009) The EU and the Health Dimension of Globalization: Playing the World Health Organization Card, in: J. Orbie and L. Tortell (Eds) The European Union and the Social Dimension of Globalization: How the EU Influences the World, pp. 131-147 (London: Routledge).

Health and Welfare Canada (1974) A New Perspective on the Health of Canadians. Ottawa: Health and Welfare Canada. 
Health-The

Wider

Dimension

$(1986)$

http://www.lenus.ie/hse/bitstream/10147/121287/1/HealthWiderDimesnionsDec1986. .pdf

Health Service Executive (2010) The Health Service Executive Tobacco Control Framework (Dublin: Health Service Executive).

Hiilamo,H., Crosbie, E. and Glantz, S.A. (2012) The evolution of health warning labels on cigarette packs: the role of precedents, and tobacco industry strategies to block diffusion. Tobacco Control, TC Online First, published on October 23, 2012 as 10.1136/tobaccocontrol-2012-050541.

Howell, F. (2004) Ireland's Workplaces, Going Smoke Free. BMJ 328: 847-848.

Howell, F. (2012) The Irish tobacco industry position on price increases on tobacco products. Tobacco Control 21 (4):514-516

Howell, F. and Allwright, S. (2005) Smoke-free public places in Ireland: how was it achieved and what has been learnt? In: Going smoke-free. The medical case for clean air in the home, at work and in public places. A report on passive smoking by the Tobacco Advisory Group of the Royal College of Physicians (London).

Howell F. and Allwright, S. (2007) Smoke-free workplaces in Ireland: culture shift through policy change, in: E. McAuliffe and K. McKenzie (Eds) The Politics of Healthcare, Achieving real reform (Liffey Press. Dublin).

Jennings, L. (2011) Tobacco smuggling: case study of a pro-health lobbying initiative. Journal of Public Affairs 11 (2): 88-92.

Joint Committee on Health and Children (1999) A National Anti-smoking Strategy: A Report on Smoking and Health (Dublin: Houses of Oireachtas).

Joint Committee on Health and Children (2001) Second Interim Report of the Subcommittee on Health and Smoking (Dublin: Houses of Oireachtas).

Joossens, L. (2004) Effective Tobacco Control in 28 Countries. European Network for Smoking Prevention.

Joossens, L and Raw, M. (2006) The Tobacco Control Scale: A New Scale to Measure Country Activity. Tobacco Control 15 (2): 247-253.

Joossens, L. and Raw, M. (2007) Progress in Tobacco Control in 30 European Countries, 2005 to 2007 . (Paper presented at $4^{\text {th }}$ European Conference on Tobacco or Health, Basel, Switzerland, October 11-13).

Joossens, L. and Raw,M. (2008). Avancees du control du tabacdans 30 pays europeens, de 2005 a2007. Bulletine Epedemiologique Hebdomadaire 21-22: 198200.

Joossens L and Raw, M. (2011) The Tobacco Control Scale 2010 in Europe.(Paper 
presented at the Fifth European Conference on Tobacco or Health, Amsterdam, 28-30 March)

http://www.ensp.org/sites/default/files/TCS 2010 in Europe FINAL.pdf

Joossens, L. and Raw, M. (2014) The Tobacco Control Scale 2013 in Europe (Paper presented at Sixth European Conference on Tobacco or Health-ECToH, Istanbul, Turkey, 26-29 March 2014) www.ectoh.org

Key, V.O. (1964) Public Opinion and American Democracy (New York: Alfred A. Knopf).

Kurzer, P. (2001) Markets and Moral Regulation: Cultural Change in the European Union (New York: Cambridge University Press).

Laffan, B. and O'Mahony, J. (2008) Ireland and the European Union (London:

Palgrave Macmillan).

Leichter, H. (1991) Free to Be Foolish: Politics and Health Promotion in the United States and Great Britain. Princeton: Princeton University Press.

Levy D.T., Currie, L. and Clancy, L. (2013) Tobacco control policy in the UK: blueprint for the rest of Europe? European Journal of Public Health 23(2):201-6. doi: 10.1093/eurpub/cks090. Epub 2012 Jul 23.

Lopez. A D., Collishaw, N.E. and Piha, T. (1994) A Descriptive Model of the Cigarette Epidemic in Developed Countries. Tobacco Control 3 (2): 242-247.

McCabe, S. (2013) 'Big Tobacco' earns $€ 104 \mathrm{~m}$ in profits from sales here. Independent. 6 September. http://www.independent.ie/business/irish/big-tobaccoearns-104m-in-profits-from-sales-here-29557124.html

McNicholas, W.T. (2004) Controlling Passive Smoking through Legislation in Ireland: An Attack on Civil Liberty or Good Public Health Policy? European Respiratory Journal 24: 337-338.

Mackenbach, J. and McKee, M. (2013) Comparative Analysis of National Health Policies, in: J.P. Mackenbach and M. McKee (Eds) Successes and Failures in Health Policy in Europe: Four Decades of Divergent Trends and Converging Challenges, pp. 255-283 (Maidenhead: Open University Press).

Mahon, E. (2001) Abortion Debates in Ireland: An Ongoing Issue, in: D. McBride Stetson (Ed.) Abortion Politics, Women's Movements and the Democratic State: A Comparative Study of State Feminism, pp. 157-180 (Oxford: Oxford University Press).

Mamudu, H. and Studlar, D.T. (2009) Multilevel Governance and Shared Sovereignty: The European Union, Member States, and the FCTC. Governance 22 (1): 73-97. 
Marmor, T. and Lieberman, E. (2004) Tobacco Control in Comparative Perspective: Eight Nations in Search of an Explanation, in: E. Feldman and R. Bayer (Eds) Unfiltered: Conflicts over Tobacco Policy and Public Health, pp. 275-291 (Cambridge: Harvard University Press).

Marsh, D. and Sharman, J. (2009) Policy Diffusion and Policy Transfer. Policy Studies 30 (3): 269-288.

Nguyen,L., Rosenquist, G. and Pekurinhenk, M. 2012. Demand for Tobacco in Europe: An Econometric Analysis of 11 Countries for the PPACTE PROJECT (Helsinki: National Institute for Health and Welfare)

O'Brien, P. (2011) MEP says Government should sue tobacco firms. Irish Examiner. 12 August. http://www.irishexaminer.com/ireland/politics/mep-says-governmentshould-sue-tobacco-firms-164008.html

O'Keeffe, C. (2014) Health minister to take on drugs and alcohol policy. Irish Examiner. 18 July. http://www.irishexaminer.com/ireland/health-minister-to-take-ondrugs-and-alcohol-policy-275865.html

Obinger, H. and Wagschal, U. (2001) Families of Nations and Public Policy. West European Politics 24 (1): 99-114.

Office of Tobacco Control .http:www.otc.ie/about_us.asp. Accessed November 27, 2006.

Outshoorn, J. (1996) The Stability of Compromise: Abortion Politics in Western Europe, in M. Githens and D. Stetson (Eds) Abortion Politics: Public Policy in CrossCultural Perspective, pp. 145-164 (New York: Routledge).

Read, M. (2006) The Republic of Ireland's Ban on Smoking in the Workplace: Reframing the Smoking Issue, in: L. Heyse, S. Resodihardjo, T Lantink, and B. Lettinga (Eds) Reform in Europe: Breaking the Barriers in Government, pp. 87-105 (Hampshire: Ashgate).

Reed, H. (2011) Irish Heart Foundation Tobacco Taxation, Smuggling \& Smoking in Ireland: A Report for the Irish Heart Foundation (Landman Economics).

Reidy, P. and Walsh, K. (2011) Economics of Tobacco: Modelling the Market for Cigarettes in Ireland (Research and Analytics Branch, Planning Division, Revenue Commissioners, Dublin).

Reilly, J. (2014) Reilly tells Big Tobacco: come ahead and sue us. Sunday Independent. 16 July

Roemer R. $(1982,1993)$ Legislative Action to Combat the World Tobacco Epidemic $1^{\text {st }}$ and $2^{\text {nd }}$ eds. (Geneva: World Health Organisation).

Rose, R. (2005) Learning from Comparative Public Policy: A Practical Guide (London: Routledge) 
Sasco A, dalla-Vorgia P., Skalkidis, Y., Katsouyianni, K. and Trichopoulos, D. (1989) An Evaluation of the Effectiveness of Tobacco-Control Legislative Policies in EEC Member States. 1948-1987: A Report (Lyon: International Agency for Research on Cancer).

Sasco A. J., dalla-Vorgia, P. and Van der Elst, P. (1992) Comparative Study of AntiSmoking Legislation in Countries of the European Economic Community (Lyon: International Agency for Research on Cancer).

Shafey, O., Eriksen, M., Ross, H. and Mackay, J. (2009) The Tobacco Atlas, $3^{\text {rd }}$ ed. (Atlanta: American Cancer Society).

Sheridan, K. (2000) Old Habits Die Hard Irish Times, 24 June.

Stepan, A. and Linz, J.J. (2011) Comparative Perspectives on Inequality and the Quality of Democracy in the United States. Perspectives on Politics 9: 841-856.

Studlar D.T. (2002) Tobacco Control: Comparative Politics in the United States and Canada. (Peterborough: Broadview Press).

Studlar D.T. (2004) Tobacco Control Policy Instruments in a Shrinking World: How Much Policy Learning? in: D. Levi-Faur and E. Vigoda-Gadot (Eds) International Public Policy and Management Policy Learning Beyond Regional, Cultural, and Political Boundaries, pp. 189-209 (New York: Marcel Dekker).

Studlar D.T. (2005) The Political Dynamics of Tobacco Control in Australia and New Zealand: Explaining Policy Problems, Instruments, and Patterns of Adoption Australian Journal of Political Science 40 (2): 255-274.

Studlar D.T. (2007) Ideas, Institutions, and Diffusion: What Explains Tobacco Control Policies in Australia, Canada, and New Zealand. Commonwealth and Comparative Politics 45 (2): 164-184.

Studlar, D.T. (2008) 'U.S. Tobacco Control: Public Health, Political Economy, or Morality Policy?" Review of Policy Research, 25 (5): 393-410.

Studlar D.T. (2009) Tobacco Control Policy in Western Europe: A Case of Protracted Paradigm Change, in: G. Capano and M. Howlett (Eds) The Dynamics and Drivers of Policy: European and North American Experiences of Policy Change pp. 71-90, (London: Routledge).

Studlar, D.T. (2012) Tobacco Control: The End of Europe's Love Affair with the Cigarette? in: S. L. Greer and P. Kurzer (Eds) European Union Public Health Policy: Regional and Global Trends, pp. 181-193 (London: Routledge).

Studlar, D.T. (2014) Multilevel Governance and the Regulation of Public Health Policies (NCDs). Paper presented at ECPR Standing Group on Regulatory Governance $-5^{\text {th }}$ Biennial Conference, Barcelona, Spain, 25-27 June. 
Studlar D.T. and Cairney, P. (2014) Conceptualizing Punctuated and NonPunctuated Policy Change: Tobacco Control in Comparative Perspective International Review of Administrative Sciences 80 (3) (forthcoming).

Studlar D.T., Christensen, K. and Sitasari, A. (2011) Tobacco Control in the EU-15: The Role of Member States and the European Union. Journal of European Public Policy 18 (5): 728-745.

Taoiseach fights tobacco lobby in EU row (2013) Business World 8 October. www.businessworld.ie/livenews.htm?a=3103322

Thomson, R. and Stokman, F.N. (2006) Research Design: Measuring Actors' Positions, Saliences, and Capabilities, in R. Thomson, F.N. Stokman, C.H .Achen and T. Konig (Ed.) The European Union Decides, pp. 25-53 (Cambridge: Cambridge University Press).

Tobacco Free Ireland: Report of the Tobacco Policy Review Group (2013) (Dublin: Department of Health).

Toshkov, D. (2013) Policy-making Beyond Political Ideology: The Adoption of Smoking Bans in Europe. Public Administration 91 (4): 448-468.

Towards a Tobacco Free Society: Report of the Tobacco Free Policy Review Group. (2000) (Dublin: Department of Health and Children).

Towards a Tobacco Free Society (2014) RCPI Policy Group on Tobacco. March. http://www.rcpi.ie/article.php?loclD=1.11.406

United Nations (2000) Economic and Social Council Committee on Economic, Social and Cultural Rights Report on the Twentieth and Twenty-first Sessions (26 April-14 May 1999, 15 November-3 December 1999) Economic and Social Council Official Records, Supplement No. 2.

Wilensky, H. (2002). Rich Democracies: Political Economy, Public Policy, and Performance (Berkeley: University of California Press).

\section{Endnotes}

\footnotetext{
${ }^{1}$ New Zealand has also announced its intentions to introduce plain packaging.

${ }^{2}$ Duina and Kurzer (2004) also do not discuss other small state advocates, but instead concentrate on larger member states plus two resistant small states, Austria and Denmark.

${ }^{3}$ The terminology of this literature is confusing, but it all discusses similar phenomena, whether it is called policy learning, policy transfer, diffusion, emulation, isomorphism, or policy borrowing. See, for example, Rose 2005; Marsh and Sharman 2009; De Francesco 2013.

${ }^{4}$ At this time Ireland was closely attached to the British economy, which also featured high cigarette taxes.
} 
${ }^{5}$ Perhaps because of an error in the document from the Health Service Executive (2010), several sources subsequently report that the first Irish cigarette package warnings were in 1991 when the EU-mandated warnings were adopted. See Reed (2011), Currie (2013a), and Currie and Clancy (2010). For the corrective, see Appendix on Irish legislation in 1979; Roemer (1982); Sasco et al. (1989; 1992); European Commission (2004); Studlar et al. (2011); Hiilamo et al. (2012).

${ }^{6}$ Ireland has legislated infrequently on tobacco, but these are usually broad documents authorising the Minister of Health to use Statutory Instruments to present specific measures to achieve the policy goals enumerated. See http://www.dohc.ie/about_us/divisions/tobacco_control/

${ }^{7}$ For an example of these problems, see Bowers' (2003) critical review of Micheál Martin's tenure as Health Minister in 2002. Tobacco is not mentioned in this article, which predates the dramatic announcement of workplace non-smoking regulations later that month. Another example occurred more recently in the 2014 cabinet reshuffle that led to the separation of the Health and Children's ministries, with James Reilly retaining responsibility for the latter, including 'co-sponsorship' of antismoking and some other aspects of public health, while Leo Varadkar became Minister for Health to deal with the 'Angola' problems. See O'Keeffe (2014) ${ }^{8}$ This included the merger of the OTC into the Health Service Executive. ${ }^{9}$ Until overturned by the EU Court of Justice in 2010, Ireland also had a minimum price for cigarettes, an unusual policy instrument.

${ }^{10}$ As in other countries, there is a debate in Ireland about how to deal with ecigarettes, but there is push by some anti-tobacco groups to treat them as medical devices, therefore subject to greater regulation. The EU declined to go this far. ${ }^{11}$ One interviewee suggested that international evidence was used more as a justification for already-decided action than genuine evidence-gathering on which to base a decision. While there obviously was some of this during the campaign for smoke-free legislation in 2003 (see Gilmore 2005), the bulk of the evidence, however, indicates that the extraordinary expense and effort, dating back to the Oireachtas committees and Tom Power's work in the Health Ministry, constituted a genuine attempt to find out 'what worked' elsewhere.

${ }^{12}$ The state of Minnesota sued US tobacco companies, and the subsequent trial resulted in the judge ordering the mass release of tobacco industry documents that have proven to be a treasure trove for analysis of industry knowledge and behaviour. ${ }^{13}$ The Irish-based tobacco companies themselves have both threatened litigation as a discouragement for legislation as well as carrying out these threats in Irish and European courts, with little success in the latter (Gilmore 2005; see Appendix). ${ }^{14}$ Eventually the US Congress passed the 2009 Family Smoking Prevention and Tobacco Control Act to satisfy the Supreme Court's objections.

${ }^{15}$ Ireland's role in EU tobacco policy has not been recognised in the broader literature on the state's relationship with the EU. See Laffan and O'Mahony 2008. 